\title{
Isotopic Analysis of Sulfur Cycling and Gypsum Vein Formation in a Natural $\mathrm{CO}_{2}$
}

\section{Reservoir}

Florence Chen ${ }^{1}$, Alexandra V. Turchyn ${ }^{1}$, Niko Kampman ${ }^{2}$, David Hodell ${ }^{1}$, Fernando Gázquez ${ }^{1}$,

${ }^{1}$ University of Cambridge, Department of Earth Sciences, Cambridge, United Kingdom

${ }^{2}$ Shell Global Solutions International, Kessler Park 1, 2288 GS Rijswijk, The Netherlands

${ }^{*}$ Corresponding author

Mailing address: University of Cambridge Department of Earth Sciences, Downing St, Cambridge CB2 3EQ, United Kingdom

Keywords: $\mathrm{CO}_{2}$ sequestration, gypsum hydration water, sulfur isotopes, oxygen isotopes, pyrite, microbial sulfate reduction 


\section{Abstract}

In order to assess the long-term security of geologic carbon storage, it is crucial to study the geochemical behavior of sulfur in reservoirs that store $\mathrm{CO}_{2}$. Fossil fuel combustion may produce mixtures of carbon dioxide and sulfur gases, and the geochemical effects of sulfur- $\mathrm{CO}_{2}$ cosequestration are poorly understood. This study examines sulfur mineralization from a core drilled in a stacked sequence of natural $\mathrm{CO}_{2}$ reservoirs near the town of Green River, Utah. These reservoirs include the Entrada and Navajo Sandstone, which are separated by the Carmel Formation caprock, and are transected by a system of $\mathrm{CO}_{2}$-degassing normal faults, through which saline $\mathrm{CO}_{2}$-charged brines discharge. Our objective in this study is to evaluate the mechanisms and timing of secondary mineral formation, particularly gypsum formation, in the $\mathrm{CO}_{2}$ reservoirs and intervening caprock. The Carmel Formation contains beds of gypsum within a fault zone. Secondary veins of gypsum exist throughout the Entrada Sandstone and Carmel Formation. We report sulfur and oxygen isotope data $\left(\delta^{34} \mathrm{~S}_{\mathrm{SO} 4}\right.$ and $\delta^{18} \mathrm{O}_{\mathrm{SO} 4}$, respectively) measured in gypsum and $\delta^{34} \mathrm{~S}$ in pyrite, and the oxygen and hydrogen isotope composition $\left(\delta^{18} \mathrm{O}\right.$ and $\delta \mathrm{D}$, respectively) of gypsum hydration water. The multiple

40 isotope approach allows us to trace the sources of sulfur in the reservoirs and, when combined with structural and petrological evidence, the progress of fluid-rock reactions and relative timing of vein mineralization.

The secondary gypsum veins in the Carmel Formation derive from mixing of fluids with two isotopically distinct sulfate sources: sulfate from the gypsum beds within the Carmel Formation and sulfate-rich brines that originate from evaporites in the underlying Carboniferous Paradox Formation. The gypsum veins in the Entrada Sandstone have a relatively wide range of $\delta^{18} \mathrm{O}_{\mathrm{sO}}$, both isotopically more enriched in ${ }^{18} \mathrm{O}$ and more depleted in ${ }^{18} \mathrm{O}$ than the primary gypsum sources. We suggest that 
some aqueous sulfate in the Entrada Sandstone may cycle through multiple valence states as it undergoes reduction and reoxidation, resulting in the replacement of its oxygen atoms and allowing

50 the occasional formation of gypsum with anomalous low $\delta^{18} \mathrm{O}_{\mathrm{sO}}$. Our data from gypsum hydration water indicates that groups of gypsum veins formed at two different times. Gypsum veins in the Entrada Sandstone and some of the veins in the Carmel Formation likely formed during Quaternary $\mathrm{CO}_{2}$-charged brine discharge events, while other veins located close to the gypsum beds in the Carmel Formation formed earlier, likely during cycles of dehydration and rehydration associated with

55 the Laramide-age (40 Mya) faulting. We conclude that calcium-sulfate mineral formation in brinefilled fractures may play an important role in inhibiting fluid migration in geologic reservoirs that contain $\mathrm{CO}_{2}$.

\subsection{Introduction}

Predicting the security of geologic $\mathrm{CO}_{2}$ storage sites requires an understanding of the geochemical behavior of the stored $\mathrm{CO}_{2}$ (Moore et al., 2005; Balashov et al., 2013). A factor that may affect this geochemical behavior is the presence of dissolved sulfur or sulfur gases within the $\mathrm{CO}_{2}$ mixture to be stored (Knauss et al., 2005; Schaef et al., 2014). This is especially significant because of the extra costs imposed by the process of removing sulfur from flue gas produced by

65 fossil fuel combustion in order to create a pure $\mathrm{CO}_{2}$ stream for carbon storage (Kaszuba et al., 2011). Sulfur- $\mathrm{CO}_{2}$ mixtures can alter reservoir composition and security in several ways. For example, dissolved $\mathrm{CO}_{2}$ forms a weak acid with water, whereas dissolved sulfur can form a strong acid, which might act to corrode reservoir and caprock minerals (Ellis et al., 2010; Kummerow and Spangenberg, 2010). Gypsum or anhydrite formation may occur in calcium- and sulfate-rich fluids at $\mathrm{pH}<5$ in brine- 
70 filled fractures, and this mineralization may impact permeability and fluid migration in $\mathrm{CO}_{2}$ reservoirs (Xu et al., 2007). At higher $\mathrm{pH}$, the addition of sulfur to $\mathrm{CO}_{2}$-charged waters may drive both an increase in rates of mineral dissolution and an eventual increase in trapping of $\mathrm{CO}_{2}$ through secondary carbonate precipitation (Ellis et al., 2010). Furthermore, sulfur can occupy multiple valence states, thus releasing or consuming electrons and influencing fluid-rock reactions by

75 impacting the redox state and $\mathrm{pH}$ of reservoir fluids (Xu et al., 2007; Kaszuba et al., 2011). Microbial activity, including microbial sulfate reduction, may also play an important role in buffering the redox chemistry of the subsurface, and this could affect toxic trace metal mobilization and transport in $\mathrm{CO}_{2}$-rich fluids (Kirk, 2011; Frerichs et al., 2014). These important processes remain poorly understood.

We report a study of sulfur mineralization in a stacked series of shallow naturally charged $\mathrm{CO}_{2}$ reservoirs and caprock systems from Green River, Utah that extend to $285 \mathrm{~m}$ below the surface. Such natural $\mathrm{CO}_{2}$ reservoirs are laboratories that provide a unique opportunity to study the behavior of $\mathrm{CO}_{2}$ in the subsurface. In such reservoirs, the chemical reactions and flow length of $\mathrm{CO}_{2}$-charged fluids are integrated over sufficiently long time-scales to enable prediction of the changes in mineralogical composition that these fluids may produce over time periods relevant to geologic $\mathrm{CO}_{2}$ storage. In the reservoirs at Green River, sulfur exists as aqueous sulfate and sulfide in the reservoir brines, with concentrations of 16-21 mmol/L and $~ 0.5-1 \mathrm{mmol} / \mathrm{L}$, respectively (Kampman et al., 2009, 2014), as sedimentary gypsum beds in the Carmel Formation, as remobilized secondary gypsum veins within the Carmel Formation and the Entrada Sandstone, and as disseminated pyrite and 90 pyrite-mineralized open fractures throughout the reservoir. Analyses of gypsum obtained from deep basin evaporite deposits, from which the $\mathrm{CO}_{2}$-charged brines originate (Wilkinson et al., 2009; 
Kampman et al., 2014), are also presented. Sulfur and oxygen isotopes of gypsum, pyrite and aqueous sulfate $\left(\delta^{34} \mathrm{~S}_{\mathrm{SO} 4}, \delta^{34} \mathrm{~S}_{\text {pyr }}, \delta^{18} \mathrm{O}_{\mathrm{SO} 4}\right)$ are used to trace the sources of sulfur in the $\mathrm{CO}_{2}$-charged groundwater systems. These isotope analyses are coupled with measurement of the isotopes of

95 gypsum hydration water $\left(\delta^{18} \mathrm{O}\right.$ and $\left.\delta D\right)$ to determine the isotopic composition of the water from which these gypsum deposits mostly recently precipitated and to distinguish primary gypsum precipitation from other processes that could form gypsum, such as dehydration and anhydrite rehydration. Our objective is to constrain the relative timing of gypsum vein formation and establish a genetic relationship between fluxes of $\mathrm{CO}_{2}$-charged brine, sulfur mobilization, and mineralization

100 of gypsum. This may yield insight into how sulfur injected into a carbon storage site reacts in the presence of $\mathrm{CO}_{2}$ and impacts the overall mineralogy and geochemistry of the reservoir.

\subsection{Geological Setting}

The natural $\mathrm{CO}_{2}$ reservoirs examined in this study consist of a stacked series of Jurassic 105 sandstone aquifers. These aquifers are located near the town of Green River, Utah in the northern part of the Paradox Basin, an area in the Colorado Plateau that extends across southeastern Utah and southwestern Colorado. At Green River, the Little Grand Wash and Salt Wash Graben fault systems extend east to west (Figure 1) and cut across the Green River Anticline, which comprises Paleozoic and Mesozoic strata (Doelling, 2002). The strata include Jurassic-aged formations: the

110 Entrada Sandstone overlies the Carmel Formation, which in turn overlies the Navajo Sandstone. The Entrada Sandstone comprises aeolian sandstones interspersed with intercalated marginal marine and sabkha deposits (Crabaugh and Kocurek, 1993). An exhumed section of the Entrada Sandstone that preserves reservoir-scale mineralogical alterations due to the past migration of reducing $\mathrm{CO}_{2}{ }^{-}$ 
charged brines is located along the Salt Wash Graben to the south of the Little Grand Wash Fault

115 (Wigley et al., 2012). The Carmel Formation was deposited in a shallow restricted sea and comprises sandstone, siltstone, shale, mudstone, and bedded gypsum (Peterson and Turner-Peterson, 1989; De Gibert and Ekdale, 1999). The lowest unit is the Navajo Sandstone, which consists of cross-bedded aeolian sandstones (see Verlander, 1995 and references therein). Below the Jurassic strata, groups of Triassic, Permian, and Pennsylvanian-aged strata are located, including the Pennsylvanian Paradox 120 Formation. The Paradox is an evaporite deposit with cyclic deposits of halite, anhydrite, and organicrich shale (Petrychenko et al., 2012). During the Quaternary, extensive dissolution of salt from the Paradox Formation led to localized collapse of a series of salt-cored anticlines in the Paradox fold and thrust belt, on which the Salt Wash and Little Grand Faults lie on the periphery (see Baars and Stevenson, 1981; Gutiérrez, 2004 and references therein). This collapse was associated with 125 alteration and mineralization of Jurassic sediments through which these saline brines flowed (Chan et al., 2000).

Fluids charged with $\mathrm{CO}_{2}$ leak to the surface through the Little Grand Wash and Salt Wash Faults and through abandoned petroleum exploration and water wells, to form a series of springs and geysers (Burnside et al. 2013; Kampman et al., 2009, 2014). These normal faults are thought to 130 have formed during the Laramide orogeny, based on K-Ar dating of the fault gouge (circa. 40 Mya; Dockrill et al., 2006). U-Th dating of surface carbonates demonstrates that $\mathrm{CO}_{2}$ has been leaking through these faults for at least 400,000 years (Burnside et al., 2013), with periodic pulses of $\mathrm{CO}_{2}$ degassing occurring after periods of local climate warming during the last 135,000 years (Kampman et al., 2012). The $\mathrm{CO}_{2}$ exists in a subcritical state throughout the Entrada Sandstone, Carmel 
135 Formation, and Navajo Sandstone and has been suggested to be crustal in origin (Heath et al., 2004), originating in much deeper strata and migrating up the fault zones in the Green River anticline. Migration of $\mathrm{CO}_{2}$-charged brines through these faults is accompanied by localized hydraulic fracturing, but there is little geological evidence to suggest that this was associated with significant slip along the fault plane (Kampman et al., 2012). The fluids sampled from $\mathrm{CO}_{2}$-degassing springs contain brine from the deep evaporite-bearing Paradox Formation mixed with this $\mathrm{CO}_{2}$-charged groundwater (Williams-Stroud, 1994; Wilkinson et al., 2009; Kampman et al., 2009, 2013, 2014). These $\mathrm{CO}_{2}$-charged fluids are mildly reducing and have trace quantities of hydrogen sulfide and methane (Kampman et al., 2009; Kampman et al., 2014).

At Green River, Utah, a drilling campaign was completed in 2012 to sample the $\mathrm{CO}_{2}$-charged 145 fluids and reservoir rocks at a site adjacent to the Little Grand Wash Fault (Kampman et al., 2013). A CS4002 Truck Mounted Core Drill recovered 322 m of core through the Entrada Sandstone, Carmel Formation, and Navajo Sandstone. The bottom of the Entrada Sandstone was located at $149 \mathrm{~m}$ below the surface and the bottom of the Carmel Formation at $199 \mathrm{~m}$ below the surface (Kampman et al., 2014). A stratigraphic log of the recovered core is presented in Figure 1. 


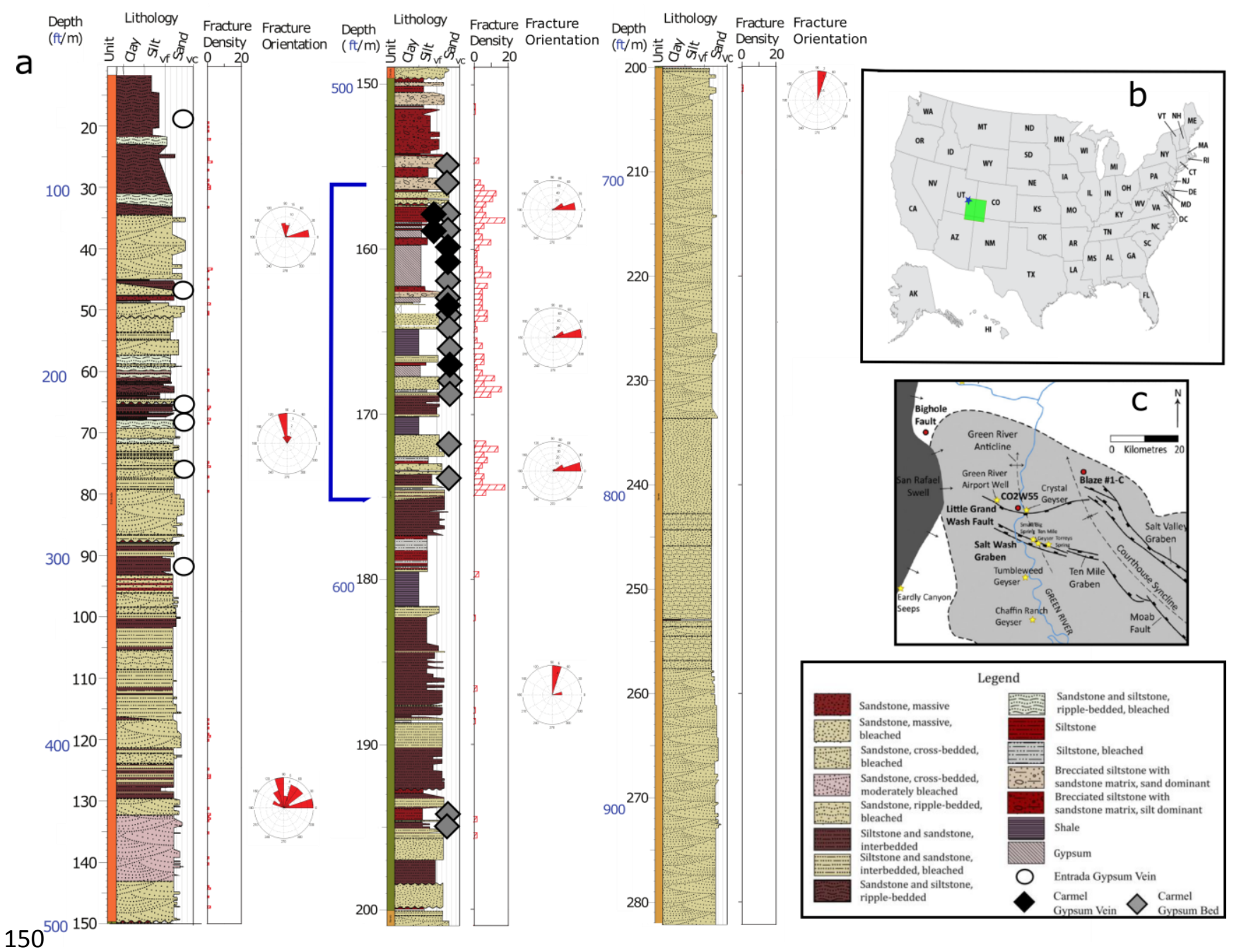

Figure 1: Stratigraphic log and location map redrafted from Kampman et al., 2014.

1a. Detailed stratigraphic log of the Entrada Sandstone, Carmel Formation and Navajo Sandstone recovered through the drilling campaign. Approximate sample locations in the Entrada Sandstone and Carmel Formation and data on fracture sets in the core are displayed. The blue line indicates the fault damage zone in the Carmel Formation (described below).

1b. Location map showing the extent of Paradox Basin and the town of Green River 

CO2W55.

The Entrada Sandstone contains intervals of cross-bedded sandstone bleached by saline, reducing, $\mathrm{CO}_{2}$-charged fluid. These intervals are extensively cross cut by fractures mineralized with gypsum and pyrite and bound by localized areas of carbonate mineralization (calcite, dolomite, and

165 ferroan dolomite) in the host-rock (Figure 2; Kampman et al., 2014). Similar paragenetic sequences are observed in outcrops of the Entrada Sandstone, exhumed along the nearby Salt Wash Graben Fault (Wigley et al., 2012). Fracture orientations are either sub-vertical or near-horizontal; these are thought to relate to regional fault movement and to hydraulic fracturing of the formation within the vicinity of the Little Grand Wash Fault, as has been observed for exhumed portions of the Salt Wash

170 Graben Fault (Kampman et al., 2012). The Carmel Formation contains local sedimentary gypsum beds and is transected by an intense zone of fracturing referred to here as 'the fault damage zone' that contains brecciated rock intensely veined with and suspended within a matrix of gypsum (Kampman et al., 2014). The gypsum-cemented breccia may be a product of localized remobilization and ductile flow of the gypsum in the gypsum beds during faulting. No gypsum veins or beds were 175 observed in sections of the core from the Navajo Sandstone. 


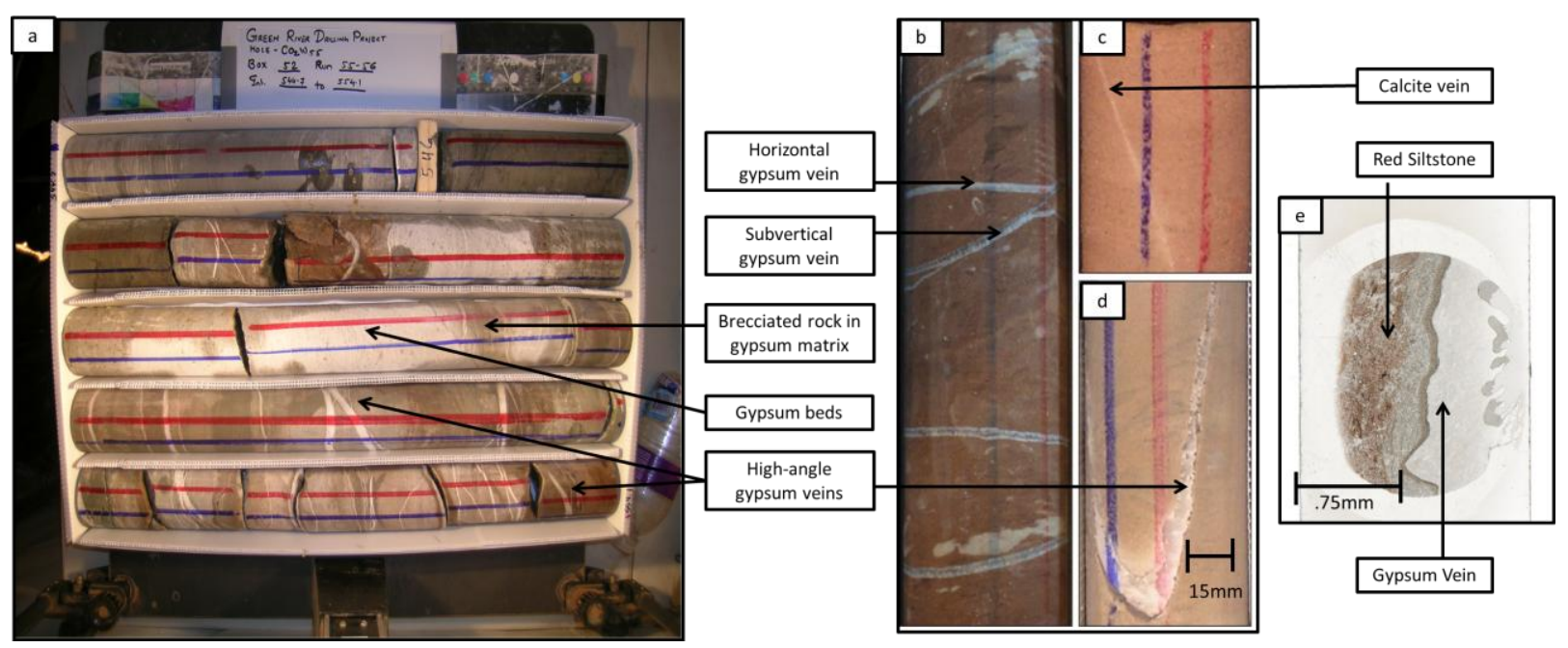

Figure 2: Images of gypsum beds and veins

2a. Core photo that depicts gypsum beds and veins in the fault damage zone (blue bracketed section in Figure 1). Each core section is $2 \mathrm{ft}$ long. The gypsum beds host blocks of brecciated rock. The gypsum veins comprise fractures filled with gypsum.

2b. Horizontal and sub-vertical gypsum-filled fractures in the Carmel Formation.

2c. High-angle calcite fracture in the Entrada Sandstone

2d. High-angle gypsum-filled fracture in the Entrada Sandstone

2e. Scanned thin section of contact between gypsum vein and siltstone in the Carmel Formation

\subsection{The use of isotopes within gypsum and gypsum hydration water}

Gypsum has the chemical formula $\mathrm{CaSO}_{4} \cdot 2 \mathrm{H}_{2} \mathrm{O}$ - therefore comprising calcium, sulfate, and two molecules of bound water, known as gypsum hydration water. The sulfur and oxygen isotopic composition of the sulfate within the gypsum crystal is similar to the sulfate in the fluid from which the gypsum precipitates, with a possible isotope fractionation during precipitation that is less than 
195 2\%o for either isotope (Lloyd, 1968; Van Stempvoort et al., 1990; Samborska et al., 2013). The exchange rate between oxygen isotopes in sulfate and surrounding water is very slow under typical conditions of low temperature and neutral $\mathrm{pH}$, so the $\delta^{18} \mathrm{O}_{\mathrm{SO} 4}$ usually reflects the last time that the sulfur atom acquired oxygen atoms and the pathway by which this occurred (Lloyd, 1967; Kusakabe and Robinson, 1977; Böttcher et al., 2001). Measurements of the $\delta^{34} \mathrm{~S}_{\mathrm{SO} 4}$ and $\delta^{18} \mathrm{O}_{\mathrm{SO} 4}$ of gypsum 200 have been used previously to explore the dynamics of evaporite basins (e.g. Alonso-Azcarate et al., 2006) and the mixing of various sulfate reservoirs (e.g. Metzger et al., 2015). The $\delta^{34} S_{\text {SO4 }}$ and $\delta^{18} \mathrm{O}_{\mathrm{SO} 4}$ of the aqueous sulfate within the $\mathrm{CO}_{2}$-charged fluids at Green River has been previously published and ranges from $9.5-10.4 \%$ and $9.0-10.6 \%$, respectively; spatial trends in these measurements are coupled to changes in the major elemental (e.g. chloride, bromine) and isotopic 205 composition $\left({ }^{87} \mathrm{Sr} /{ }^{86} \mathrm{Sr}, \delta^{18} \mathrm{O}_{\mathrm{H} 2 \mathrm{O}}\right)$ of the $\mathrm{CO}_{2}$-charged brines (Kampman et al., 2014). These spatiocompositonal trends reflect mixing between sulfate-rich $\mathrm{CO}_{2}$-charged brines derived from the underlying Carboniferous Paradox Formation, with sulfate in meteoric groundwater-brine mixtures from the Carmel Formation (Kampman et al., 2014).

The $\delta^{18} \mathrm{O}$ and $\delta \mathrm{D}$ isotopic composition of the gypsum hydration water has been used to 210 calculate the isotopic composition of the mother water from which the gypsum mostly recently precipitated (Sofer, 1978, Hodell et al., 2012; Evans et al., 2015). Analysis of the gypsum hydration water can provide important constraints on the fluid sources that formed the veins and subsequent mechanisms of gypsum dehydration and rehydration, thus revealing information about the history and relative timing of vein formation. 


\section{Experimental Methods}

\subsection{Sampling of Gypsum}

Gypsum was obtained by drilling plugs with $1.5 \mathrm{~cm}$ diameters on core sections from well CO2W55 (Kampman et al., 2013). Veins from a range of depths in the Entrada Sandstone and Carmel

220 Formation (hereafter called secondary gypsum veins) and sedimentary beds in the Carmel Formation (hereafter called gypsum beds) were sampled. Secondary gypsum veins were identified relative to gypsum beds based on their morphology and cross-cutting relationships. The secondary gypsum veins in the Carmel Formation are found in two separate locations: near the stratigraphic height of the gypsum beds (depths between 158-175 m) and deeper than the gypsum beds (depths greater

225 than $190 \mathrm{~m}$ ). The former are the veins within the heavily brecciated fault-damage zone. Gravimetric analysis of sample water loss after dehydration was used to identify the weight percent of water present in calcium-sulfate minerals (Gaquez, et al., 2015). When samples contained a significantly smaller weight percent of water that is expected for gypsum (20.9\%), X-ray diffraction (XRD) analysis was used to distinguish gypsum from anhydrite.

\subsection{Sulfur and Oxygen Isotopes in Gypsum and Pyrite}

Gypsum powder was obtained by drilling directly into the gypsum vein or bed. To extract the sulfate for sulfur and oxygen isotope analysis, the powder was left in deionized water overnight. The effluent containing the aqueous sulfate from the dissolution was then separated, and a 235 supersaturated barium chloride solution $(50 \mathrm{~g} / \mathrm{l}$ ) was added to precipitate barium sulfate. The barium sulfate precipitate was rinsed with $6 \mathrm{M} \mathrm{HCl}$ and several times in deionized water and dried in a $35^{\circ} \mathrm{C}$ oven overnight prior to analysis. 
Pyrite $\left(\mathrm{FeS}_{2}\right)$ was extracted from hand samples through digestion of 5-10 grams of whole rock powder in a chromium chloride solution (Canfield et al., 1986). $60 \mathrm{~mL}$ of $1 \mathrm{M} \mathrm{CrCl}_{2}$ and $0.5 \mathrm{M} \mathrm{HCl}$ solution was added to the whole rock powder and nitrogen gas was bubbled for 2-3 hours, releasing hydrogen sulfide gas from the sulfide minerals. The hydrogen sulfide gas was passed through a vessel containing $0.1 \mathrm{M} \mathrm{HNO}_{3}$ to remove chlorine gas and then into a trap filled with $\mathrm{AgNO}_{3}$ and $10 \%$ $\mathrm{NaOH}$ solution. The silver sulfide precipitated was analyzed for its sulfur isotope composition.

The sulfur and oxygen isotopic composition of the sulfate from the gypsum veins and beds 245 and the sulfur isotope composition of the sulfide from the pyrite were measured in the Godwin Laboratory at the University of Cambridge. For $\delta^{18} \mathrm{O}_{\mathrm{sO} 4}$, a Temperature Conversion Element Analyzer (TC/EA) was used to pyrolyze the barite at $1450^{\circ} \mathrm{C}$ and produce $\mathrm{CO}$, which was measured by continuous flow Gas Source Isotope Ratio Mass Spectrometry (ThermoScientific Delta V Plus). Samples were run in duplicate or triplicate with the NBS-127 Standard (8.6\%o), and the average and

250 standard deviation of the replicate analyses is reported. All $\delta^{18} \mathrm{O}_{\mathrm{SO} 4}$ reported are relative to $\mathrm{V}$-SMOW (Vienna-Standard Mean Ocean Water). For $\delta^{34} \mathrm{~S}_{\mathrm{SO} 4}$, the barite was combusted at $1030^{\circ} \mathrm{C}$ in a Flash Elemental Analyzer (Flash-EA), and the sulfur dioxide produced was measured by continuous flow Gas Source Isotope Ratio Mass Spectrometry (ThermoScientific, Delta V Plus). Samples for sulfur isotope analysis were run alongside the NBS-127 standard (20.3\%o). Multiple measurements of the 255 standard were made in each run, and the standard deviation of the standards is reported as $\delta^{34} S$ standard deviation in Tables 1-3. Blind replicates were run for $10 \%$ of the samples. For most runs, the $2 \sigma$ standard deviation was less than $0.4 \%$ for $\delta^{34} S$ (based on the replicate analyses of the standards) and $0.8 \%$ for $\delta^{18} \mathrm{O}$ (based on the duplicate or triplicate analyses of a single sample), 
though a small number of samples had slightly larger standard deviations of $0.6 \%$ and $1.5 \%$, respectively. All $\delta^{34} \mathrm{~S}_{\mathrm{SO} 4}$ reported are relative to VCDT (Vienna- Canyon Diablo Troilite).

\subsection{Oxygen and Hydrogen Isotopes in Gypsum Hydration Water}

The $\delta^{18} \mathrm{O}$ and $\delta \mathrm{D}$ of gypsum hydration were analyzed by heating the gypsum in vacuo using a bespoke offline extraction system consisting of six vacuum lines contained within a modified gas chromatography (GC) oven (Gázquez et al., 2015). Prior to the extraction, powdered gypsum samples were dried in an oven at $35^{\circ} \mathrm{C}$ overnight. Each extraction consisted of five samples and one gypsum standard. Gypsum samples ( 200 mg) were loaded into disposable 12-mm Pyrex tubes, placed in the GC oven, and connected to individual stainless vacuum lines. The hydration water was recovered after drying in a 6-mm break-seal tube by cryogenic trapping in liquid nitrogen at $-196{ }^{\circ} \mathrm{C}$.

270 Samples were placed under vacuum $\left(\sim 5 \times 10^{-3} \mathrm{mbar}\right)$ for at least 3 hours at room temperature to remove adsorbed water from the gypsum. Subsequently, gypsum hydration water was released by slowly heating the sample to $400^{\circ} \mathrm{C}$. Once the oven reached $400^{\circ} \mathrm{C}$, this temperature was maintained for 40 minutes to ensure all water in the lines was recovered in the cryogenic traps.

Oxygen and hydrogen isotopes of the water were measured simultaneously by cavity ring

275 down spectroscopy using a L1102-i Picarro water isotope analyzer and A0211 high-precision vaporizer at the Godwin Laboratory at the University of Cambridge (Hodell et al., 2012). Each sample was injected nine times into the vaporizer. Memory effects from previous samples were avoided by rejecting the first three analyses. Values for the final six injections were averaged with typical in-run precision of $\pm 0.05 \%$ for $\delta^{18} \mathrm{O}$ and $\pm 0.4 \%$ ofor $\delta D(1 \sigma)$. Calibration of results to $\mathrm{V}$ SMOW was achieved by analyzing internal standards before and after each set of 7 or 8 samples. 
Internal standards were calibrated against V-SMOW, GISP, and SLAP. All results are reported in parts per thousand (\%o) relative to $\mathrm{V}$-SMOW. The external error of the method was $\pm 0.1 \%$ for $\delta^{18} \mathrm{O}$ and $\pm 0.6 \%$ for $\delta D(1 \sigma)$, as estimated by repeated analysis $(n=9)$ of an internal gypsum standard extracted together with the samples in each run.

\section{Results}

The sulfur and oxygen isotopic composition of the secondary gypsum veins in the Entrada Sandstone (37 Samples -Table 1) and of the Carmel Formation's gypsum beds (19 samples) and secondary gypsum veins (35 Samples - Table 2) are presented in Figure 3, along with the sulfur and oxygen isotope data from samples of the Paradox Formation evaporites (8 Samples - Table 3).

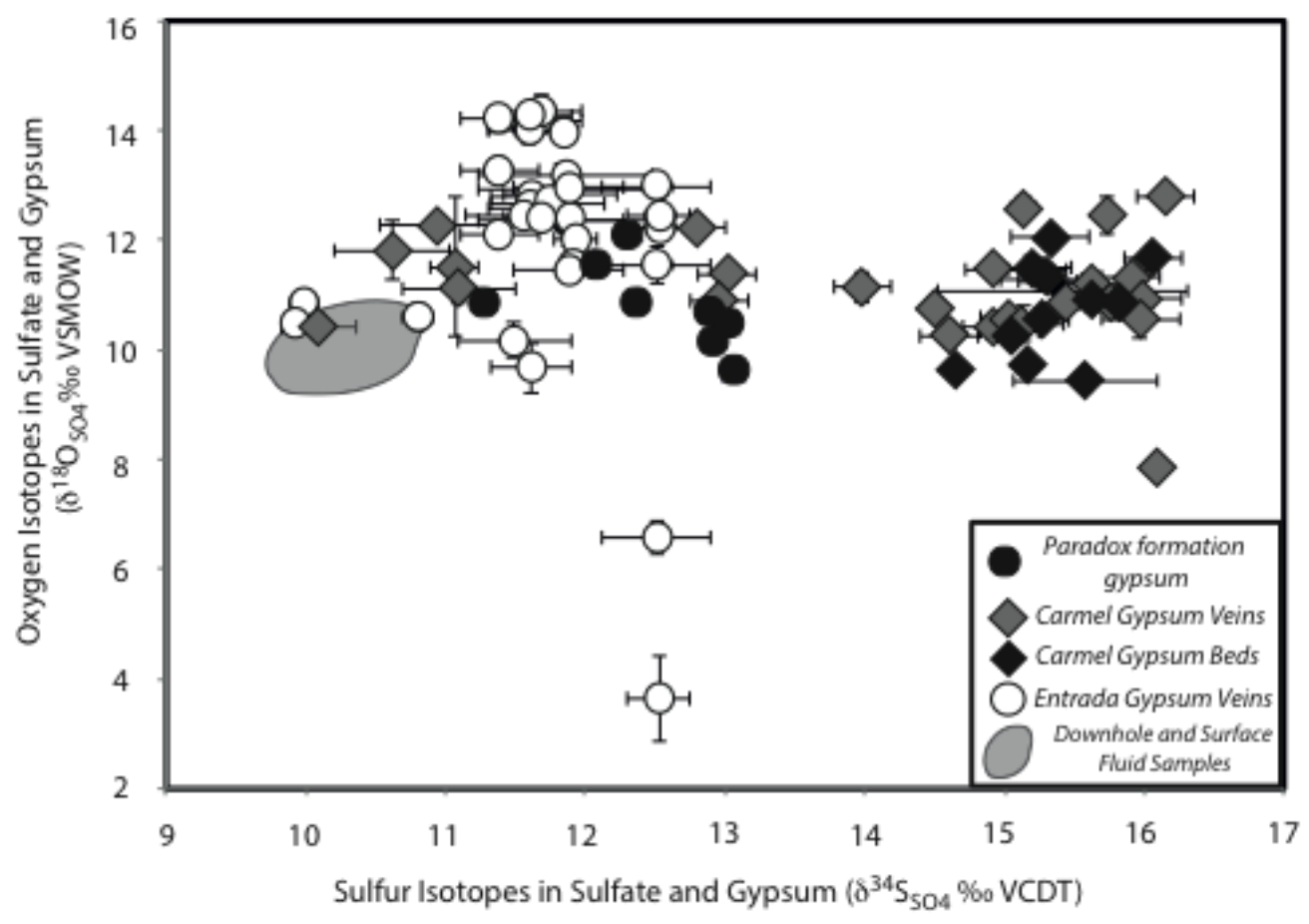


Figure 3: Results for $\delta^{34} \mathrm{~S}_{\mathrm{SO} 4}$ and $\delta^{18} \mathrm{O}_{\mathrm{SO} 4}$ of gypsum beds in the Carmel Formation (black diamonds), secondary gypsum veins in the Carmel Formation (grey diamonds) and Entrada Sandstone (open circles), and evaporites from the Paradox Formation (black circles). $\delta^{34} \mathrm{~S}_{\mathrm{SO} 4}$ and $\delta^{18} \mathrm{O}_{\mathrm{SO} 4}$ of dissolved sulfate in fluid samples, reported in Kampman et al., 2014, are also shown.

In Figure 3, the area in grey is the previously reported sulfur and oxygen isotopes from aqueous sulfate measured in both downhole fluid sampling and surface springs (Kampman et al., 2014). The gypsum beds in the Carmel Formation have a $\delta^{34} \mathrm{~S}_{\mathrm{SO} 4}$ between $14.7 \%$ and $16.1 \%$ and a $\delta^{18} \mathrm{O}_{\mathrm{sO} 4}$ between $7.8 \%$ and $12.0 \%$. The secondary gypsum veins in the Carmel Formation have a $\delta^{34} \mathrm{~S}_{\mathrm{SO} 4}$ between $10.1 \%$ and $16.1 \%$ and a similar range of $\delta^{18} \mathrm{O}_{\mathrm{SO} 4}$ between $7.6 \%$ and $12.8 \%$. In contrast, the secondary gypsum veins in the Entrada Sandstone have a narrow range of $\delta^{34} \mathrm{~S}_{\mathrm{SO} 4}$ between $10.6 \%$ and $12.5 \%$, but a wide range of $\delta^{18} \mathrm{O}_{\mathrm{sO}}$ between $3.6 \%$ ond $14.4 \%$, skewed by two analyses that are isotopically depleted in ${ }^{18} \mathrm{O}$ compared to the rest of the analyses. These two analyses were part of twelve measurements taken across the same vein (Table 1). The sulfur and oxygen isotopic composition of the Paradox Formation evaporites ranges between $11.3 \%$ and $13.1 \%$ for $\delta^{34} \mathrm{~S}_{\mathrm{SO} 4}$ and between $9.7 \%$ and $12.2 \%$ o for $\delta^{18} \mathrm{O}_{\mathrm{SO} 4}$ (Table 3 ).

Twenty-five samples were analyzed for $\delta^{18} \mathrm{O}$ and $\delta \mathrm{D}$ of gypsum hydration water (Table 4,

\section{Figure 4).}




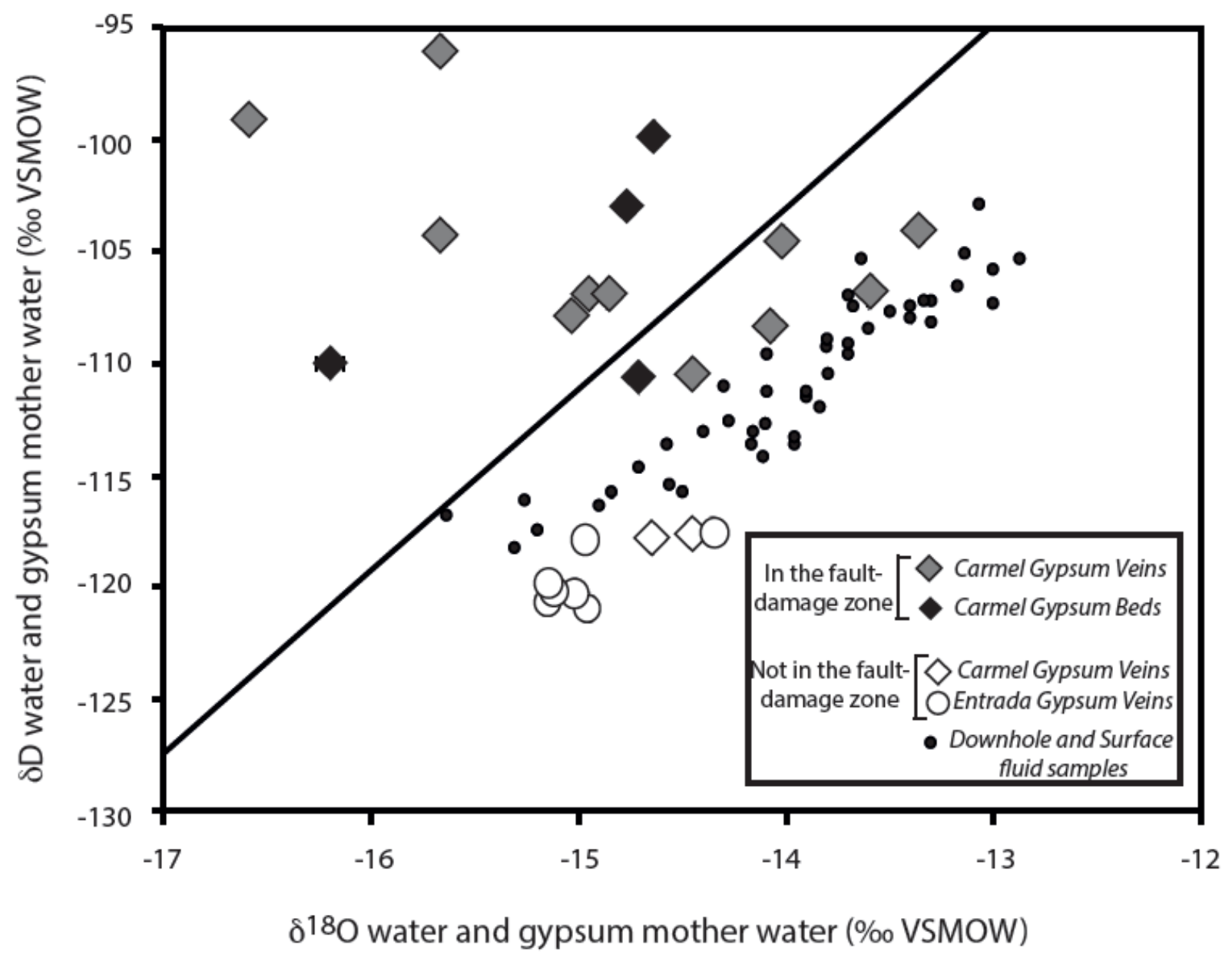

Figure 4: $\delta^{18} \mathrm{O}$ and $\delta \mathrm{D}$ of gypsum mother water after correction for the isotopic fractionation for water isotopes during gypsum formation. The downhole fluid sample data from Kampman et al., 2014 is included for reference. The Local Meteoric Water Line is indicated by the solid line. The samples outside of the fault-damage zone all fall below the Local Meteoric Water Line in both oxygen and hydrogen isotope space, while the majority of the samples in the fault-damage zone fall above this line.

The $\delta^{18} \mathrm{O}$ of gypsum hydration water ranged from $-12.7 \%$ to $-9.4 \%$, while $\delta \mathrm{D}$ was between $-137.7 \%$ o and $-113.2 \%$. The isotope fractionation of oxygen isotopes between gypsum hydration water and 
330 mother water $\left(\alpha^{18} \mathrm{O}_{\text {gyp-H2O }}=1.004\right)$ is independent of temperature in the $12-37^{\circ} \mathrm{C}$ range (Gonfiantini and Fontes, 1963; Fontes and Gonfiantini, 1967; Hodell et al., 2012). The hydrogen isotope fractionation between gypsum hydration water and mother water $\left(\alpha D_{\left.\text {gyp- } \mathrm{H}_{2 O}=0.981\right)}\right.$ is largely temperature-independent in this range, though there may be a very slight temperature effect of .00012 per ${ }^{\circ} \mathrm{C}$ (Hodell et al., 2012). We use these isotope fractionation factors to calculate the 335 isotopic composition of the gypsum mother water from which the gypsum formed; for the secondary gypsum veins in the Entrada Sandstone, this mother water had a narrow isotopic composition ( $\delta^{18} \mathrm{O}$ between $-15.2 \%$ and $-14.4 \%$ ond $\delta \mathrm{D}$ between $-117.6 \%$ o to $-121.0 \%$ ), similar to previous measurements of the isotopic composition of the downhole and surface fluids (Figure 4 previous data from Kampman et al., 2014). In contrast, gypsum beds in the Carmel Formation 340 were hydrated by water with more variable isotopic compositions (between $-16.2 \%$ and $-14.6 \%$ o for $\delta^{18} \mathrm{O}$ and from $-110.7 \%$ o to $-99.8 \%$ for $\left.\delta \mathrm{D}\right)$. There is a similarly wide range of oxygen and hydrogen isotopes in the hydration water from the secondary gypsum veins in the Carmel Formation ( $\delta^{18} \mathrm{O}$ between $-16.6 \%$ and $-13.4 \%$ and $\delta \mathrm{D}$ between $-117.9 \%$ ond $-96.1 \%$ ) (Figure 4 ). Six additional samples (Table 4) from within the fault damage zone were identified as anhydrite 345 based on XRD and on the fact that they yielded less than $12 \%$ water calculated gravimetrically, which is considerably less than that expected for pure gypsum (20.9\%). Five of these six samples yielded less than $5 \%$ water.

Isotopic variability with depth, including measurements of $\delta^{34} S_{\text {pyrite, }}$ is shown in Figure $\mathbf{5}$. The $\delta^{34} S_{\text {pyrite }}$ in the Entrada Sandstone ranges between $-47.4 \%$ and $18.8 \%$ o (Table 5 - 13 samples;

350 Figure 5a); the $\delta^{34} S_{\text {pyrite }}$ appears to get isotopically heavier with depth in the Entrada Sandstone. The $\delta^{34} S_{\text {pyrite }}$ near the base of the Entrada Sandstone has a similar sulfur isotopic composition to 
the secondary gypsum veins. The $\delta^{34} \mathrm{~S}_{\mathrm{SO} 4}$ of the gypsum (Figure 5b) throughout the Entrada Sandstone and in the base of the Carmel Formation is similar, while most of the samples in the fault damage zone yield $\delta^{34} \mathrm{~S}_{\mathrm{SO} 4}$ that is $\sim 3 \%$ higher. The deuterium-excess or $\mathrm{d}$-excess (Figure $\mathbf{5 c}$ ) is 355 the deviation of the deuterium measurements from the Local Meteoric Water Line and is calculated as $\delta D-8^{*} \delta^{18} \mathrm{O}$ (Dansgaard, 1964). In the Entrada Sandstone and the base of the Carmel Formation, the d-excess values are similar, which parallels the pattern observed in the $\delta^{34} \mathrm{~S}_{\mathrm{SO} 4}$ of these secondary veins. However, the data in the fault-damage zone is more scattered and ranges from $1.9 \%$ o to values as high as $33.7 \%$. 

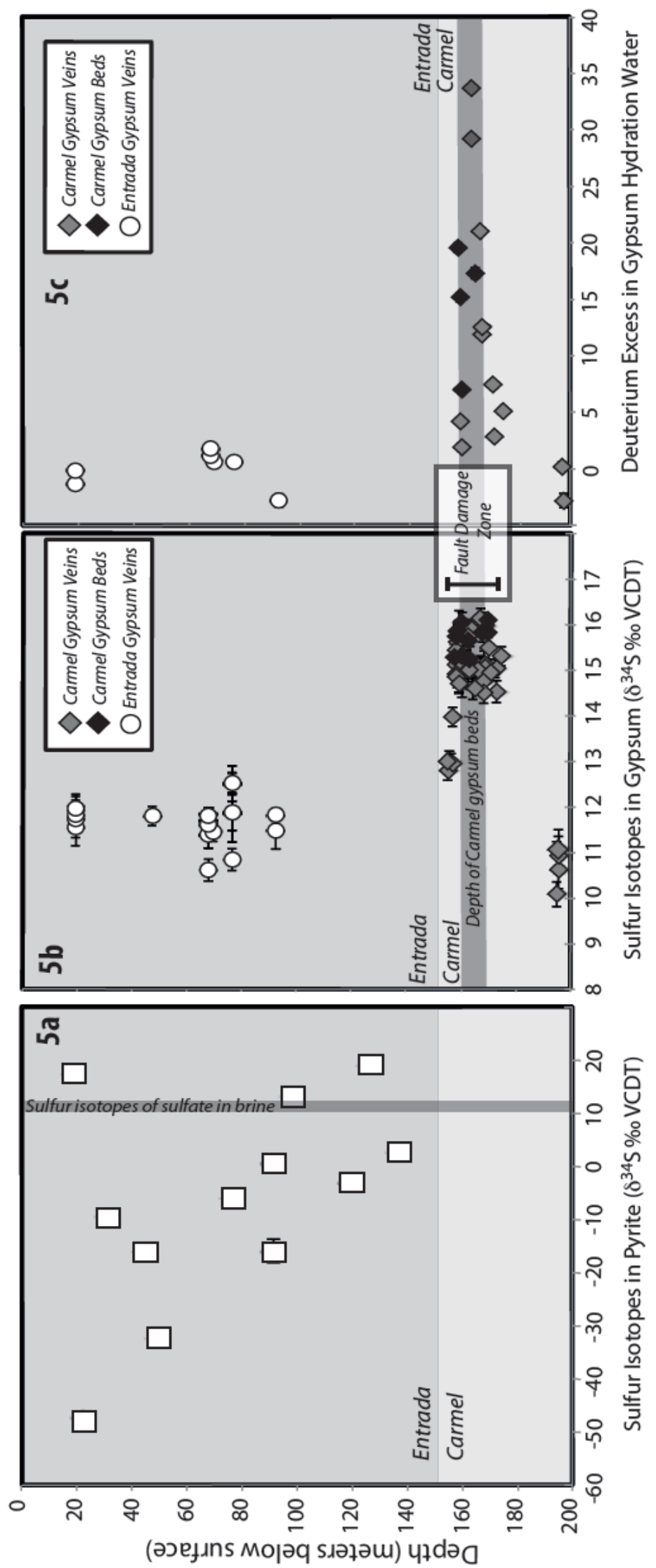
Figure 5: Depth Plots

5a. Depth plot of $\delta^{34} S_{\text {pyrite }}$ for Entrada Sandstone samples that contain disseminated pyrite.

5b. $\delta^{34} \mathrm{~S}_{\mathrm{SO} 4}$ of the gypsum beds and secondary gypsum veins plotted against depth. Within the Carmel Formation, the secondary gypsum veins located in the fault-damage zone are isotopically similar to the gypsum beds, while those located further from the gypsum beds are isotopically similar to the secondary veins in the Entrada Sandstone.

5c. Depth plot of deuterium excess (also called d-excess) for gypsum hydration water in the gypsum beds and secondary gypsum veins. Some samples in the fault-damage zone have high d-excess, and samples at shallower or deeper locations have low d-excess.

\section{Discussion}

The primary goal of this study is to explore the formation of secondary gypsum veins in the natural $\mathrm{CO}_{2}$-charged reservoirs at Green River. We propose that an understanding of secondary gypsum vein formation provides information on faulting and fracturing within the reservoir and on the behavior of co-existing sulfate- and $\mathrm{CO}_{2}$-charged brines. The discussion of our data is split into two parts. First, we examine mixing between sources of sulfur and processes that could affect the

380 isotopic composition of gypsum hydration water to understand the timing of gypsum bed and secondary gypsum vein formation in the Carmel Formation. We then use the isotopic composition of gypsum hydration water and oxygen isotopes in sulfate to understand the factors that influenced secondary gypsum vein formation in the Entrada Sandstone. 


\subsection{Formation of the Gypsum Beds and Secondary Gypsum Veins in the Carmel Formation}

\subsubsection{Mixing between sulfate derived from the Paradox Formation evaporites and}

\section{Carmel Formation gypsum beds}

Aqueous sulfate was previously reported in the downhole and surface fluids from Green

River; the interpretation of these analyses was that sulfate in the reservoir fluids originates largely from the anhydrite in the Paradox Formation, with some mixing of sulfate from gypsum in the fracture zone within the Carmel Formation (Kampman et al., 2014). In theory, if the source of the sulfate in the $\mathrm{CO}_{2}$-charged brine was the dissolution of evaporites from the Paradox Formation mixed with dissolved gypsum from the Carmel Formation, then the downhole fluid samples should plot between the isotopic composition of the Paradox Formation and that of the Carmel Formation in sulfur and oxygen isotope space (Figure 3). However, aqueous sulfate in the reservoir fluids has a lower sulfur isotopic composition than either proposed end member (Figure 3). There is no evidence for an additional source of sulfate that is lower in $\delta^{34}$. Instead, we suggest that a small amount of 400 hydrogen sulfide existed in the downhole fluids reported in Kampman et al. (2014) and was homogenized with the sulfate from the dissolution of the Paradox Formation anhydrites prior to sulfur isotope analysis. Previous studies at Crystal Geyser and the Little Grand Wash Fault zone detected hydrogen sulfide through gas flux measurements or by the detectable odor of $\mathrm{H}_{2} \mathrm{~S}$ gas (Allis et al., 2005; Haszeldine et al., 2005). The aqueous hydrogen sulfide could derive either from 405 microbial sulfate reduction in the reservoir fluids or subsurface pyrite dissolution in the Carmel Formation or Entrada Sandstone.

A simple isotope mass balance illustrates this scenario. If the sampled fluid contained 19-20 $\mathrm{mmol} / \mathrm{L}$ of sulfate and $\sim 0.5-1 \mathrm{mmol} / \mathrm{L}$ of $\mathrm{H}_{2} \mathrm{~S}$, which is consistent with the measured oxidation state 
of the fluids (Kampman et al., 2014), to shift the $\delta^{34} S$ of the aqueous sulfate down from $12.5 \%$ o

410 (Paradox Formation) to 10.2\%o (measured aqueous sulfate) would require hydrogen sulfide with a of $\delta^{34} S$ of approximately $-35 \%$. This low $\delta^{34} S$ is typical for hydrogen sulfide produced during microbial sulfate reduction or otherwise found in pyrite (e.g. Böttcher et al., 2004).

The relatively wide range of $\delta^{34} \mathrm{~S}_{\mathrm{SO} 4}$ measured in gypsum veins from the Carmel Formation indicates that these veins may have formed from multiple sulfur sources. The secondary gypsum 415 veins in the Carmel Formation lie on an isotope mixing line between the sulfur isotopic composition of the gypsum beds in the Carmel Formation and the isotopic composition of the evaporites in the Paradox Formation (Figure 6). A mixing model is proposed to explain the sulfur and oxygen isotopic composition of the secondary gypsum veins in the Carmel Formation (Figure 6). In this calculation, two end members are considered, the first being the Carmel gypsum beds, and the second being the 420 evaporites in the Paradox Formation. Themeasured $\delta^{34} \mathrm{~S}_{\mathrm{SO} 4}$ of the downhole fluids is not used as the second end-member because, as outlined above, these measurements may have been compromised during sampling by oxidation of sulfide in the fluid. 


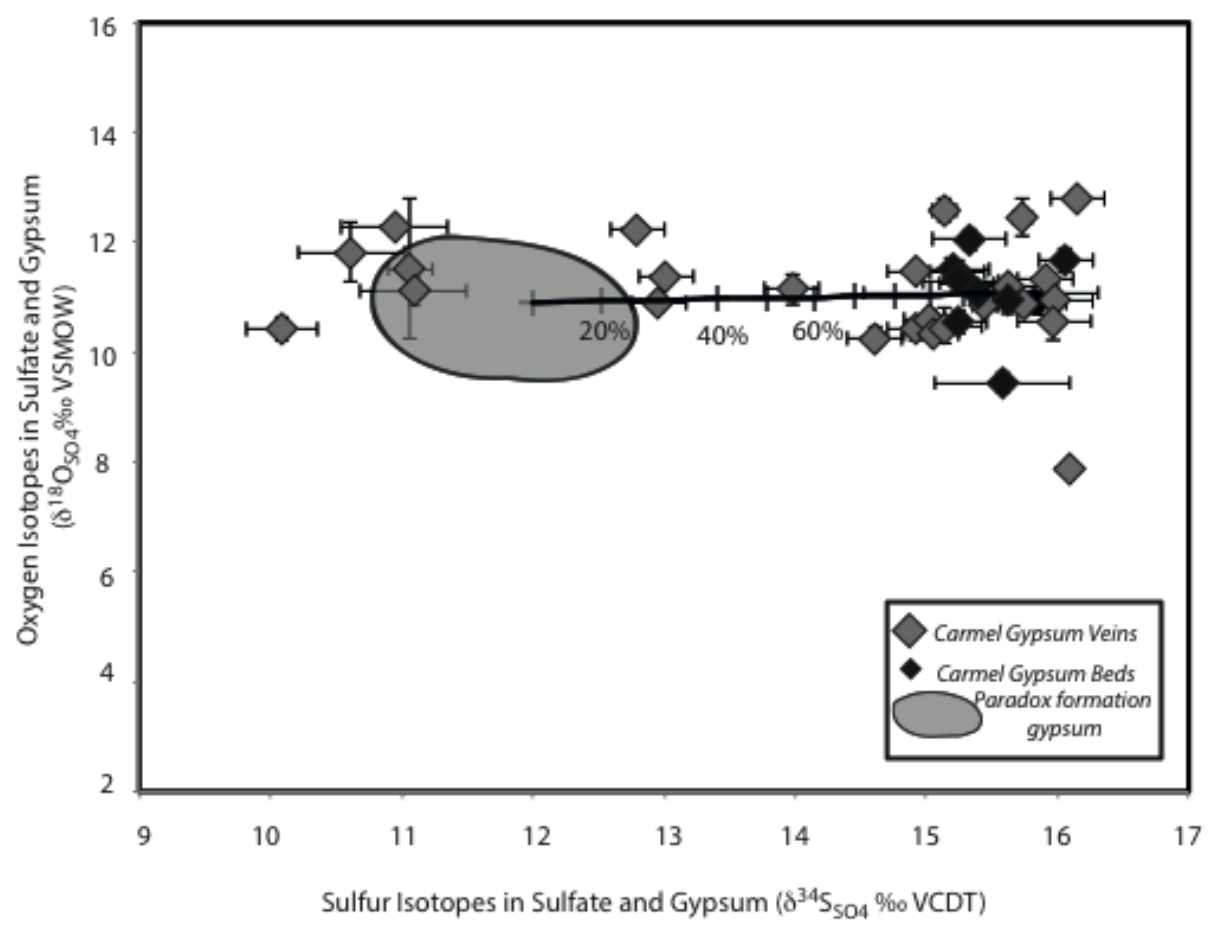

Figure $6-\delta^{34} \mathrm{~S}_{\mathrm{SO} 4}$ and $\delta^{18} \mathrm{O}_{\mathrm{SO} 4}$ of the gypsum beds and secondary gypsum veins in the Carmel Formation. A mixing line is shown with two end members: the gypsum from the beds and the sulfate from the Paradox Formation.

As shown in Figure 6, the secondary gypsum veins in the Carmel Formation are either similar to the gypsum beds in the Carmel Formation or exist close to, or slightly above (higher $\delta^{18} \mathrm{O}_{\mathrm{sO}}$ ), the mixing 430 line between the beds in the Carmel Formation and the sulfate in the Paradox Formation. These results suggest that the secondary gypsum veins in the Carmel Formation are produced when gypsum beds within the Carmel Formation dissolve, reprecipitate, and are mixed with varying amounts of sulfate from the Paradox evaporites. This conclusion is supported by data shown in Figure $\mathbf{5 b}$, where the sulfur isotope composition of the veins in the fault damage zone are of a similar isotopic composition to the gypsum beds, while those that are deeper in the formation and 
further away from the gypsum beds in the fault damage zone are closer to the $\delta^{34} S_{\text {so } 4}$ of the underlying Paradox Formation.

This conclusion is also supported by the oxygen and hydrogen isotopic composition of the gypsum hydration water from the samples that are located in the Carmel Formation but outside the

440 fault-damage zone. The secondary gypsum veins within the Carmel Formation (and Entrada Sandstone) that are not in the fault-damage zone have low d-excess, which are comparable to those of the modern fluids (Figure $\mathbf{5 c}$ ). On the other hand, the $\delta^{18} \mathrm{O}, \delta \mathrm{D}$, and d-excess of the mother water for the secondary gypsum veins and gypsum beds in the fault-damage zone span a wide range, and some of these samples plot far from the downhole fluids in $\delta^{18} O$ and $\delta D$ isotope space. The 445 difference in gypsum hydration water data between the secondary veins in the fault-damage zone and in the deeper parts of the Carmel indicate that two fluid sources - one that flows within the fault-damage zone and one that originates from a deeper formation - must have formed these veins.

\subsubsection{Processes that may have affected the formation of gypsum in the fault damage zone} The $\delta^{18} \mathrm{O}$ and $\delta \mathrm{D}$ of some gypsum beds and secondary gypsum veins in the fault damage zone deviate from the modern Local Meteoric Water line, since they show higher d-excess (Figure 5c). The typical d-excess in natural waters usually does not exceed 20\%o (Dansgaard, 1964), while values of up to $33 \%$ are calculated for some samples in the fault-damage zone (Table 4). Previous studies have shown that negative d-excess can be attributed to meteoric or seawater evaporation

455 (Gat and Gonfiantini, 1981; Evans et al., 2015), yet such large and positive d-excess is rarely observed. 
One possibility is that the gypsum in the fault damage zone formed through the hydration of anhydrite to gypsum with a low water-to-mineral ratio, such that the supply and exchange of water is limited relative to the amount of anhydrite (Bath et al., 1987). Anhydrite hydration to gypsum under equilibrium conditions in which the newly-hydrated gypsum no longer exchanges with the surrounding water can be modeled by the isotope distillation equation - also known as Rayleigh fractionation - for equilibrium closed systems (Matsubaya and Sakai, 1973; Gat and Gonfiantini, 1981):

$$
R / R_{0}=f^{(\alpha-1)}
$$

\section{Eq 1.}

Where $\mathrm{R}$ denotes the ${ }^{18} \mathrm{O}$ to ${ }^{16} \mathrm{O}$ or ${ }^{2} \mathrm{H}$ to ${ }^{1} \mathrm{H}$ ratio, $\alpha$ is the isotope fractionation factor between hydration water and mother water, and $f$ is the fraction of original water remaining in solution. In principle, as groundwater hydrates anhydrite to gypsum, the isotopes in this water distill into the gypsum, leaving the residual water isotopically evolved. As a result, the oxygen or hydrogen isotope composition of the newly-hydrated gypsum exhibits non-equilibrium isotope composition.

470 Note that a limited supply of water is essential for this hypothesis; otherwise, it would not be possible for the isotopes of this water to evolve to such a large degree. Using Equation 1 to calculate the evolution of the water isotopes during this process (with the isotope fractionation factors given by Sofer (1978)) yields a line for isotopic composition of the mother water with a slope of $\sim-5$ in a cross plot of $\delta D$ versus $\delta^{18} O$ (Matsubaya and Sakai, 1973). The slope is negative because the

475 hydration of anhydrite with limited amounts of water favors the heavy oxygen atom $\left({ }^{18} \mathrm{O}\right)$ but the light hydrogen isotope $\left({ }^{1} \mathrm{H}\right)$ (Sofer, 1978), and this process results in depletion in ${ }^{18} \mathrm{O}$ and enrichment in ${ }^{2} \mathrm{H}$ in the remaining water. Thus, the line cuts across the Local Meteoric Water Line, and the dexcess is high. The starting point of such a line occurs where $f=1$, since this represents the theoretical 
original water; in this case, the original water is most likely to consist of local groundwater, which was collected as downhole fluid samples in Kampman, et al. (2014). Thus, the range of possible isotopic compositions for these original waters would be near the downhole fluids, and is indicated by the light gray shaded region slightly below the Local Meteoric Water Line in Figure 7. This region encompasses all the downhole fluids as well as the surface fluids and veins that plot near the downhole samples.

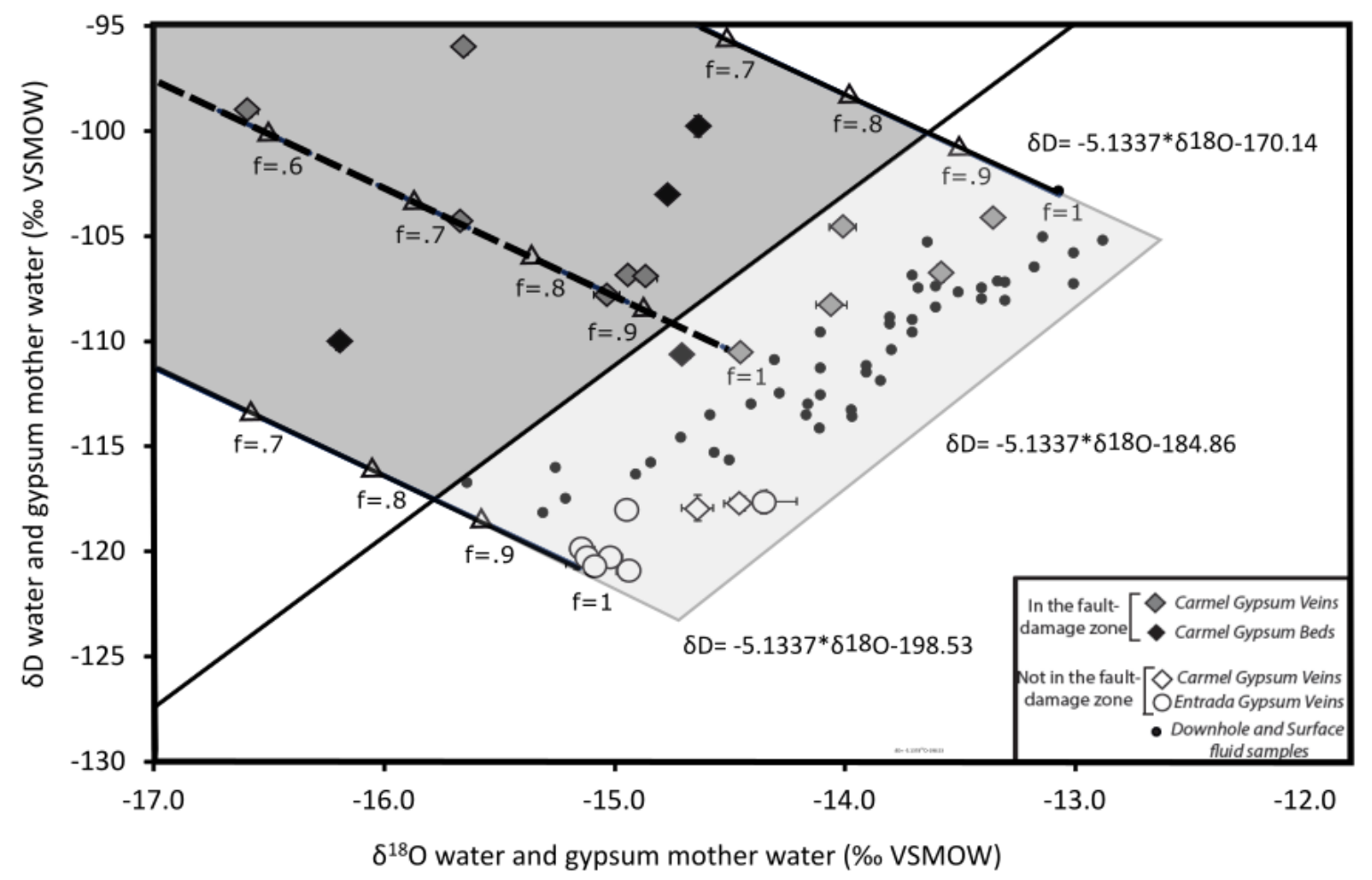

Figure 7: $\delta^{18} \mathrm{O}$ and $\delta \mathrm{D}$ of gypsum mother water measured in this study and in previous studies on downhole and surface fluids. The light gray shaded region and dark gray shaded region represent, respectively, the range of isotopic compositions for local groundwater and the isotopic compositions that could result from the theoretical isotope fractionation trend that occurs when anhydrite is hydrated with limited amounts of water. This isotope fractionation is modeled through the isotope distillation equation, which produces lines with slopes of $\sim-5$, as shown, for $\delta D v . \delta^{18} O$. 
The fraction of original water remaining $(f)$ is indicated by the triangle symbols on each line.

For example, if the original water is assumed to have the isotopic composition of the deepest gypsum vein at $173.6 \mathrm{~m}$, the evolution of $\delta^{18} \mathrm{O}$ and $\delta \mathrm{D}$ isotopes calculated with Equation 1 is shown by the dashed line that cuts across the center of the Local Meteoric Water Line, and five measurements from secondary gypsum veins fall close to this line. The lines that form the boundary of the dark gray shaded region are calculated by applying Equation 1 to the lightest and heaviest of the samples in the light gray shaded region. Thus, the dark gray region indicates the expected range of isotopic compositions for gypsum formed through anhydrite hydration with limited water, given the range of isotopic compositions for original water shown in Figure 7. All of the anomalous 505 samples with large, positive d-excess are encompassed within the dark gray region. This demonstrates that the process modeled by Equation 1 may have formed the gypsum with high $d$ excess measured in the Carmel Formation.

The Carmel Formation is a low-permeability stratigraphic unit that serves as a seal for this $\mathrm{CO}_{2}$ reservoir and a regional caprock for the fluids in the Navajo Sandstone (Dockrill and Shipton,

510 2010; Kampman et al., 2014). The fault damage zone within the Carmel Formation is composed mostly of siltstones and shales, with some regions of fine-grained sandstone (Figure 1). Thus, permeability and hydraulic conductivity within the fault damage zone are low, and flow of water is limited, so anhydrite hydration could have occurred under conditions of limited water availability in this geological setting.

515 This anhydrite hydration may have occurred within cycles of partial dehydration and rehydration after sedimentary deposition. Additional evidence for some dehydration of the gypsum 
includes the fact that twenty-nine individual veins were measured, and the six that were identified as anhydrite were found within the fault-damage zone (Table 4). Primary anhydrite can form when concentrated brines flow into dry supratidal environments, while secondary anhydrite can form through heating and dehydration of gypsum (Shearman, 1985; Hardie, 1987). Since the Carmel Formation represents a marine highstand tract system (Blakey et al., 1996), it is likely that the calcium-sulfate minerals originally deposited were gypsum and that primary anhydrite was formed through subsequent dehydration during burial, and then subsequent rehydration produced the gypsum that is currently found in the fault damage zone of the Carmel Formation. If the dehydration 525 of gypsum was partial, then lighter isotopes would be released first, while heavier ${ }^{18} \mathrm{O}$ and deuterium would remain within the hydration water. Rehydration of this partially dehydrated gypsum could further alter the isotopic composition. The $\delta D$ of the gypsum that was newly rehydrated through this process would be higher than that of the original gypsum, while the $\delta^{18} \mathrm{O}$ could be either higher or lower, depending on the fraction of original water remaining (f). Thus, this process of partial 530 dehydration and rehydration may have affected some of the samples in the Carmel.

The timing of these dehydration and rehydration events may be related to the age of the faults, since the samples that plot above the Local Meteoric Water Line in $\delta^{18} \mathrm{O}$ and $\delta \mathrm{D}$ isotope space are all located within the fault damage zone. The inferred Laramide age (around 40 Mya) of these faults (Dockrill, 2006) also coincides with the estimated timing of deepest burial for the Jurassic 535 strata in this portion of the Paradox Basin, since the Carmel Formation was buried to a depth of approximately $2.4 \mathrm{~km}$, and heated to circa $105^{\circ} \mathrm{C}$, temperatures sufficient to stabilize the formation of anhydrite or hemihydrated calcium sulfate (basanite) (Nuccio and Condon, 1996). The cataclasite and anhydrite cemented fault breccia may therefore have formed during a late Laramide faulting, 
with subsequent hydration to gypsum occurring during exhumation. Thus, gypsum hydration water measurements may not always record the composition of local meteoric water or groundwater, but may instead constitute evidence for the specific events and processes that enabled gypsum formation.

\subsection{The generation of the secondary gypsum veins in the Entrada Sandstone}

from those measured in the Carmel Formation, since these veins do not fall near the same binary mixing line as the veins in the Carmel Formation (Figure 3), suggesting that the isotopic composition of these samples cannot be explained by simple mixing between sulfate derived from gypsum beds and Paradox evaporite minerals. In contrast to the secondary gypsum veins in the Carmel Formation,

550 which have a narrow range of $\delta^{18} \mathrm{O}_{504}$ and a wide range of $\delta^{34} \mathrm{~S}_{\mathrm{SO} 4}$, the secondary gypsum veins in the Entrada Sandstone have a small range of $\delta^{34} \mathrm{~S}_{\mathrm{SO} 4}$, which is similar to the $\delta^{34} \mathrm{~S}_{\mathrm{SO} 4}$ from the underlying Paradox Formation, but a much wider range of $\delta^{18} \mathrm{O}_{504}$. The $\delta^{18} \mathrm{O}_{504}$ of the secondary gypsum veins in the Entrada Sandstone lies mostly higher than the $\delta^{18} \mathrm{O}_{504}$ measured from their source (the Paradox evaporites), although there are two measurements that lie far below (Figure 3). We note that these

555 low $\delta^{18} \mathrm{O}_{504}$ measurements were made in a vein for which multiple measurements were conducted; it is difficult to understand how much significance to assign to these two values. There was no aspect of their appearance to indicate that the low $\delta^{18} \mathrm{O}_{\mathrm{SO}}$ values are due to an anomaly that would justify excluding the samples from consideration. 
The overall wider range of $\delta^{18} \mathrm{O}_{\mathrm{SO} 4}$ (including the two 'low samples') may provide information

560 on the behavior of sulfate during fluid-rock reactions of $\mathrm{CO}_{2}$-charged brines in the Entrada Sandstone. The oxygen isotope composition of sulfate is set during its formation, since the sulfur-oxygen bond in sulfate is exceptionally strong and does not break to exchange oxygen atoms with surrounding water, except at exceptionally low $\mathrm{pH}(<1)$ or exceptionally high temperatures $\left(>300^{\circ} \mathrm{C}\right.$, see Hoering and Kennedy, 1957; Zeebe, 2010; Rennie and Turchyn, 2014). Therefore, the $\delta^{18} \mathrm{O}_{\text {SO4 }}$ should reflect the 565 incorporation of oxygen atoms into the sulfate molecule from the last time the sulfur atom underwent oxidationfrom molecular oxygen (e.g. $\mathrm{O}_{2}$ ), from water, or from both. When sulfide oxidation proceeds in the absence of atmospheric oxygen (e.g. via iron), then all the oxygen atoms in the resultant sulfate derive from surrounding water (Calmels et al., 2007). During sulfide oxidation, intermediate valence state sulfur species, such as sulfite $\left(\mathrm{SO}_{3}{ }^{2-}\right)$ can also be produced; both these 570 species and the original sulfate may exchange oxygen atoms with ambient water at low temperatures, and the resulting sulfate would reflect this isotope equilibration (Brunner and Bernasconi, 2005; Surkov et al., 2012; Boschetti, et al., 2013). Therefore, the $\delta^{18} \mathrm{O}_{\mathrm{sO} 4}$ of sulfate produced from sulfide or sulfur oxidation tends to range between 0 and $\sim 25 \%$ above the water in which the oxidation took place. the secondary gypsum veins in the Entrada Sandstone would be that a local source of sulfur or sulfide with a near-homogenous $\delta^{34} \mathrm{~S}$ was oxidized through different oxidation pathways, producing sulfate with a range of $\delta^{18} \mathrm{O}_{\mathrm{sO} 4}$. The likeliest source of reduced sulfur that could be oxidized would be hydrogen sulfide or primary pyrite within the Entrada Sandstone and Carmel Formation; however 580 these both have very low $\delta^{34} \mathrm{~S}$, which is inconsistent with the measured $\delta^{34} \mathrm{~S}$ of the gypsum (Figure 
5a). Alternately, gypsum dissolution would contribute sulfate with a uniform $\delta^{34} \mathrm{~S}$, but it would be unexpected for this process alone to produce a range of $\delta^{18} \mathrm{O}_{\mathrm{sO} 4}$.

A more intriguing explanation for the range of isotope data in the secondary gypsum veins in the Entrada Sandstone is the possibility of a quantitative sulfur cycle within the fluids in the reservoir,

585 close to some of the smaller gypsum veins. This redox cycling of sulfur would include microbial sulfate reduction to form hydrogen sulfide or another intermediate valence state sulfur species followed by near quantitative reoxidation of this species to form new sulfate. During this reoxidation, the resulting aqueous sulfate would gain new oxygen atoms from reactions with the surrounding water (Böttcher et al., 1998). Partial equilibration with water during this oxidation 590 would result in exceptionally enriched values up to $25 \%$ o higher than the $\delta^{18} \mathrm{O}$ of the water. The majority of our analyses lie at $9 \%$ o to $15 \%$, which is $\sim 25 \%$ o higher than the fluid $\delta^{18} \mathrm{O}$ of $-15 \%$ o to -13 \%o measured in Kampman, et al. (2014). However, because the reduction and oxidation of sulfur species would be quantitative, no sulfur atoms would be added or removed, so the sulfur isotopic composition of the sulfate formed by this quantitative cycling would be equal to the $\delta^{34} S$ of the 595 original sulfate. For microbial sulfate reduction, a source of sulfate and organic matter is required (e.g. Böttcher et al., 2004). In the case of Green River, the organic matter is likely carried in the anoxic brine itself (Kampman et al., 2014). Sulfide produced during this sulfate reduction would have a variety of possible fates. Some sulfide could undergo precipitation to pyrite, as shown by the presence of disseminated pyrite within the reservoirs, while other amounts could remain in the 600 reservoir fluids or could be reoxidized back to sulfate. The fluids sampled from the Entrada Sandstone may provide evidence for sulfide reoxidation, since they are ferrous iron-rich from 
reductive hematite dissolution (Kampman et al., 2014). The reductive dissolution of hematite by sulfide proceeds via the following reaction (Dos Santos Afonso and Stumm, 1992):

$$
4 \mathrm{Fe}_{2} \mathrm{O}_{3}+\mathrm{H}_{2} \mathrm{~S}+14 \mathrm{H}^{+} \leftrightarrow \mathrm{SO}_{4}^{2-}+8 \mathrm{Fe}^{2+}+8 \mathrm{H}_{2} \mathrm{O}
$$

605 During this reaction, the ferric iron in hematite reoxidizes sulfide back to sulfate, with some of the liberated ferrous iron eventually being incorporated into pyrite (Kampman et al., 2014). Thus, it is possible that a near-quantitative microbial sulfur cycle, comprising microbial sulfate reduction and sulfide oxidation via ferric iron reduction in the presence of the acidic $\mathrm{CO}_{2}$-rich fluids, may provide a source of sulfide to drive the dissolution of hematite and sandstone bleaching. This redox cycling of 610 sulfur would involve only a very small amount of sulfate in the reservoir fluids because the $\delta^{34} S$ in the newly formed sulfate is nearly unchanged, but the $\delta^{18} \mathrm{O}$ is variable. The small amounts of sulfate formed through redox cycling could be trapped in gypsum, if gypsum precipitation was fast relative to the residence time of sulfate in the reservoir.

This process would require gypsum precipitation in the Entrada Sandstone that occurs much

615 more rapidly than the vein formation over millions of years that may have taken place in the Carmel Formation. The gypsum hydration water data from the secondary gypsum veins that formed outside of the fault damage zone suggests recent precipitation. These secondary gypsum veins, which are located in the Entrada Sandstone and lower part of the Carmel Formation, have gypsum hydration water with the same isotope composition as the $\mathrm{CO}_{2}$-charged brines measured in these formations 620 and the underlying Navajo Sandstone (Kampman et al., 2014; Figure 4). Thus, the fluids that hydrated the gypsum in the Entrada Sandstone likely have the same genesis as the $\mathrm{CO}_{2}$-charged brines, which have been leaking through these faults for at least the past 135,000 years (Kampman et al., 2012). Consequently, the gypsum hydration water data suggests that the veins in the Entrada 
Sandstone formed during these Quaternary discharge events on thousand-year timescales. This 625 timescale of precipitation is fast when compared to the secondary gypsum veins in the fault-damage zone that transect gypsum beds in the Carmel Formation and may have formed through dissolution, dehydration, and reprecipitation events concurrent with faulting during exhumation over millions of years.

The evidence from multiple isotope analysis for different time periods of gypsum vein formation at Green River is helpful for understanding the behavior of sulfur in carbon storage sites. First, it is useful to compare the formation of secondary gypsum veins and carbonate minerals at Green River to other studies of reservoirs in which both $\mathrm{CO}_{2}$ and sulfur species are present. Numerical modeling predicts that secondary anhydrite and pyrite will precipitate to fill fractures in reservoirs that contain $\mathrm{CO}_{2}$ mixed with sulfate or aqueous sulfide (Kaszuba et al, 2011; Xu et al., 635 2007). The addition of sulfur to reservoir fluids may lead to dissolution of other minerals, which can increase alkalinity and lead the formation of secondary carbonates (Ellis et al., 2010). Specifically, sulfide oxidation by ferric iron (e.g. Equation 2) can increase $\mathrm{pH}$ and can help to promote carbonate precipitation (Soetaert et al., 2007), and precipitation of secondary carbonate veins indeed occurs at Green River near the reaction fronts where sandstone bleaching through iron dissolution is taking 640 place (Wigley et al., 2012). Our results confirm that adding sulfur into a $\mathrm{CO}_{2}$ reservoir can result in the deposition of secondary carbonate and secondary gypsum or anhydrite, with the presence of small amounts of sulfur exerting an important control on mineral paragenesis.

In addition, the gypsum hydration water data indicates that vein formation may have affected reservoir permeability. The most common calcium-sulfate mineral in the reservoirs at Green 645 River is gypsum because the current temperatures at this shallow natural analogue site are $15-18^{\circ} \mathrm{C}$ 
(Kampman et al., 2014), which are not sufficiently high for stable anhydrite formation (Xu et al., 2007; Kaszuba et al., 2011). In the fault-damage zone, the evidence from the gypsum hydration water measurements for cycles of dehydration and rehydration may indicate that aquifer temperatures decreased from over $\sim 57^{\circ} \mathrm{C}$, at which anhydrite and gypsum solubility are equal, to the current water 650 temperature at which gypsum is the stable phase (García-Ruiz et al., 2007). This supports a Laramide age for the formation of these faults and suggests that fault movement and anhydrite cementation of the fault breccia occurred during peak burial in the Paleogene, or shortly after (Nuccio and Condon, 1996). Since the gypsum hydration water in the fault-damage zone shows little influence of the modern local water, this may suggest that gypsum and secondary anhydrite vein formation in this region sealed off this zone from further fluid flow, thus substantially decreasing its permeability. Further reactive-transport modeling will help ascertain the effect of these mineralization reactions on retardation of $\mathrm{CO}_{2}$ transport within the fault zone and $\mathrm{CO}_{2}$ charged reservoirs.

Finally, the presence of pyrite and gypsum with a wide range of $\delta^{34} S$ and $\delta^{18} \mathrm{O}_{\text {sO4 }}$, respectively in the Entrada Sandstone indicates that microbial sulfate reduction is currently occurring in the 660 reservoir. This production of hydrogen sulfide can cause dissolution of hematite grains, sandstone bleaching, and production of ferrous iron, thus affecting the mineralogical composition of the natural carbon reservoir. This can serve as a model for the behavior of $\mathrm{SO}_{2}$ gas, which is the most common sulfur species emitted from fossil fuel combustion and can disproportionate to form hydrogen sulfide (Ellis et al., 2010). Our data can be combined with further studies of sulfide and pyrite formation at Green River to demonstrate how microbial sulfate reduction may occur in natural carbon reservoirs and produce a variety of different sulfur species that alter these reservoirs through fluid-rock reactions. 


\section{Conclusions}

This study presented $\delta^{34} \mathrm{~S}, \delta^{18} \mathrm{O}$, and $\delta \mathrm{D}$ from aqueous sulfate, pyrite, gypsum, and gypsum hydration water within a natural $\mathrm{CO}_{2}$ reservoir near Green River, Utah. The isotopic data for gypsum and gypsum hydration water from the Paradox evaporites, Carmel beds, Carmel veins, and Entrada veins displayed a wide range in $\delta^{34} \mathrm{~S}, \delta^{18} \mathrm{O}$, and $\delta \mathrm{D}$. Our data and a mixing model demonstrated that the Paradox evaporites and Carmel beds constituted the main sources of dissolved sulfate in the

$675 \mathrm{CO}_{2}$-charged reservoir brines. Hydration water measurements indicated that secondary gypsum veins in the Entrada Sandstone formed during more recent periods of hydraulic fracturing and fluid flow during the Quaternary, while partial dehydration and rehydration associated with regional faulting may have formed the gypsum beds and veins in the Carmel Formation. The formation of secondary gypsum veins in conjunction with secondary carbonates suggested that secondary mineralization can trap and inhibit leakage of both $\mathrm{CO}_{2}$ and sulfur in geologic reservoirs. Additional research is necessary to confirm this finding in different environments and to determine its implications for the long-term viability of $\mathrm{CO}_{2}-\mathrm{SO}_{2}$ co-sequestration.

The aqueous sulfate and pyrite measurements as well as the $\delta^{18} \mathrm{O}_{\mathrm{sO} 4}$ data from the secondary veins in the Entrada Sandstone indicated that an active microbial sulfur cycle may be present.

685 Evidence for this included the presence of sulfate and sulfide with a large range of isotopic compositions and the differences in $\delta^{18} \mathrm{O}$ and $\delta \mathrm{D}$ between the hydration waters from the secondary gypsum veins in the Entrada Sandstone and in the fault-damage zone of the Carmel Formation. The sulfide produced from microbial sulfate reduction may form pyrite, remain in the reservoir fluids, or be reoxidized. All three of these processes may be taking place in both the Entrada Sandstone and 
690 the Carmel Formation. The effect of adding $\mathrm{CO}_{2}$ into a system where microbial sulfate cycling is present remains enigmatic (Morozova et al., 2010; Kirk, 2011). For the sulfur-bearing minerals at Green River, more analyses of pyrite veins and additional sulfide samples are necessary to determine whether microbial sulfate reduction has occurred. This demonstrates the importance of further work to better understand whether microbes can alter the properties of geologic carbon storage sites by causing different sulfur species to form and affect geochemical properties of reservoirs. 


\section{Acknowledgments}

We would like to thank Tim Lowenstein and Javier Garcia Veigas for providing samples for the Paradox Formation, and Hazel Chapman and Peter Scott for exceptional help with Green River

715 sample selection and location. Technical help was gratefully received from Beth O'Connell, Clare Hedgecott, James Rolfe, Ian Mather, and Jason Day. Conversations with David Johnston and Francis Macdonald helped the conceptual development of data analysis, and Harold Bradbury and Andrea Erhardt provided helpful comments on the manuscript. Funding was provided by the Fulbright Commission, Mellon Mays Undergraduate Fellowship and the Harvard-Cambridge Summer

720 Fellowship to FC, European Research Council (ERC) StG 307582 to AVT, ERC WIHM Project (\#339694) to DAH, the Natural Environment Research Council to the Carbon Research into Underground Storage consortium (NE/F004699/1), the UK Department of Energy and Climate Change through a CCS Innovation grant, and Shell Global Solutions International. We thank DOSECC for carrying out the drilling. 


\section{References}

Allis, R., Bergfeld, D., Moore, J., McClure, K., Morgan, C., Chidsey, T., Heath, J. and McPherson, B. (2005). Implications of results from $\mathrm{CO}_{2}$ flux surveys over known $\mathrm{CO}_{2}$ systems for long-term monitoring. In: Fourth Annual Conference on Carbon Capture and Sequestration DOE/NETL. Department of Energy.

Alonso-Azcárate, J., Bottrell, S. and Mas, J. (2006). Synsedimentary versus metamorphic control of $\mathrm{S}, \mathrm{O}$ and $\mathrm{Sr}$ isotopic compositions in gypsum evaporites from the Cameros Basin, Spain. Chemical Geology, 234(1-2), pp.46-57.

Balashov, V., Guthrie, G., Hakala, J., Lopano, C., Rimstidt, J. and Brantley, S. (2013). Predictive modeling of $\mathrm{CO}_{2}$ sequestration in deep saline sandstone reservoirs: Impacts of geochemical kinetics. Applied Geochemistry, 30, pp.41-56.

Baars, D. and Stevenson, G. (1981). Tectonic evolution of the Paradox basin, Utah and Colorado. In: Rock Mountain Association of Geologists - Field Conference.

Bath, A., Darling, W., George, I. and Milodowski, A. (1987). ${ }^{18} \mathrm{O} /{ }^{16} \mathrm{O}$ and ${ }^{2} \mathrm{H} /{ }^{1} \mathrm{H}$ changes during progressive hydration of a Zechstein anhydrite formation. Geochimica et Cosmochimica Acta, 51(12), pp.3113-3118.

Baune, C. and Böttcher, M. (2010). Experimental investigation of sulphur isotope partitioning during outgassing of hydrogen sulphide from diluted aqueous solutions and seawater. Isotopes in Environmental and Health Studies, 46(4), pp.444-453.

Blakey, R., Havh, K., Jones, L. (1996). Stratigraphic Analysis of Eolian Interactions with Marine and Fluvial Deposits, Middle Jurassic Page Sandstone and Carmel Formation, Colorado Plateau, U.S.A. SEPM Journal of Sedimentary Research, Vol. 66.

Boschetti, T. (2013). Oxygen isotope equilibrium in sulfate-water systems: A revision of geothermometric applications in low-enthalpy systems. Journal of Geochemical Exploration, 124, pp. 92-100.

Böttcher, M., Oelschläger, B., Höpner, T., Brumsack, H. and Rullkötter, J. (1998). Sulfate reduction related to the early diagenetic degradation of organic matter and "black spot" formation in tidal sandflats of the German Wadden Sea (southern North Sea): stable isotope (13C, 34S, 180) and other geochemical results. Organic Geochemistry, 29(5-7), pp.1517-1530. 
Böttcher, M., Thamdrup, B. and Vennemann, T. (2001). Oxygen and sulfur isotope fractionation during anaerobic bacterial disproportionation of elemental sulfur. Geochimica et Cosmochimica Acta, 65(10), pp.1601-1609.

Böttcher, M., Khim, B., Suzuki, A., Gehre, M., Wortmann, U. and Brumsack, H. (2004). Microbial sulfate reduction in deep sediments of the Southwest Pacific (ODP Leg 181, Sites 1119-1125): evidence from stable sulfur isotope fractionation and pore water modeling. Marine Geology, 205(1-4), pp.249-260.

Breit, G. and Goldhabe, M. (1990). Authigenic Barite as an Indicator of Fluid Movement through Sandstones Within the Colorado Plateau. Journal of Sedimentary Research, 60 (6), pp. 884-896.

Brunner, B. and Bernasconi, S. (2005). A revised isotope fractionation model for dissimilatory sulfate reduction in sulfate reducing bacteria. Geochimica et Cosmochimica Acta, 69(20), pp.4759-4771.

Burnside, N., Shipton, Z., Dockrill, B., and Ellam, R.M. (2013). Man-made versus natural $\mathrm{CO}_{2}$ leakage: a 400 k.y. history of an analogue for engineered geological storage of $\mathrm{CO}_{2}$. Geology, 41 (4), 471-474.

Calmels, D., Gaillardet, J., Brenot, A. and France-Lanord, C. (2007). Sustained sulfide oxidation by physical erosion processes in the Mackenzie River basin: Climatic perspectives. Geology, 35(11), p.1003.

Canfield, D., Raiswell, R., Westrich, J., Reaves, C. and Berner, R. (1986). The use of chromium reduction in the analysis of reduced inorganic sulfur in sediments and shales. Chemical Geology, 54(1-2), pp.149-155.

Chan, M. A., Parry, W. T., and Bowman, J. R. (2000). Diagenetic hematite and manganese oxides and fault-related fluid flow in Jurassic sandstones, southeastern Utah. AAPG Bulletin, 84(9), 1281-1310.

Claypool, G., Holser, W., Kaplan, I., Sakai, H. and Zak, I. (1980). The age curves of sulfur and oxygen isotopes in marine sulfate and their mutual interpretation. Chemical Geology, 28, pp.199-260. In K. Pye, ed., The Dynamics and Environmental Context of Aeolian Sedimentary 
Systems, London Geological Society Special Publication 72, Bath, UK: The Geological Society Publishing House, pp. 103-126..

Dansgaard, W. (1964). Stable isotopes in precipitation. Tellus, 16(4), pp.436-468.

De Gibert, J. and Ekdale, A. (1999). Trace Fossil Assemblages Reflecting Stressed Environments in the Middle Jurassic Carmel Seaway of Central Utah. Journal of Paleontology, 73(4), pp.711-720.

Doelling, H., 2002. Interim Geologic Map of the San Rafael Desert 30' x 60' Quadrangle, 958 Emery and Grand Counties, Utah. Open. Repository 404, Utah Geological Survey.

Dockrill, B. (2006). Understanding Leakage from a Fault-Sealed $\mathrm{CO}_{2}$ Reservoir in East-Central Utah: A Natural Analogue Applicable to $\mathrm{CO}_{2}$ Storage. Ph.D thesis, Trinity College Dublin.

Dockrill, B. and Shipton, Z. (2010). Structural controls on leakage from a natural CO2 geologic storage site: Central Utah, U.S.A. Journal of Structural Geology, 32(11), pp.1768-1782.

Dos Santos Afonso, M. and Stumm, W. (1992). Reductive dissolution of iron (III)(hydr) oxides by hydrogen sulfide. Langmuir, 8(6), pp. 1671-1675.

Ellis, B., Crandell, L. and Peters, C. (2010). Limitations for brine acidification due to $\mathrm{SO}_{2}$ coinjection in geologic carbon sequestration. International Journal of Greenhouse Gas Control, 4(3), pp.575-582.

Evans, N., Turchyn, A., Gázquez, F., Bontognali, T., Chapman, H. and Hodell, D. (2015). Coupled measurements of $\delta 180$ and $\delta D$ of hydration water and salinity of fluid inclusions in gypsum from the Messinian Yesares Member, Sorbas Basin (SE Spain). Earth and Planetary Science Letters. 430: 499-510.

Fontes, H.C., Gonfiantini, R. (1967). Fractionnement isotopique de I'hydrogene dans l'eau de cristallisation du gypse. Comptes Rendus de l'Académie des Sciences, 265, pp. 4-6.

Frerichs, J., Rakoczy, J., Ostertag-Henning, C. and Krüger, M. (2014). Viability and Adaptation Potential of Indigenous Microorganisms from Natural Gas Field Fluids in High Pressure Incubations with Supercritical $\mathrm{CO}_{2}$. Environmental Science \& Technology, 48(2), pp.1306-1314.

García-Ruiz, J., Villasuso, R., Ayora, C., Canals, A. and Otálora, F. (2007). Formation of natural gypsum megacrystals in Naica, Mexico. Geol, 35(4), p.327. 
Gat, J. and Gonfiantini, R. (1981). Stable isotope hydrology. Vienna: International Atomic Energy Agency.

Gázquez, F., Mather, I., Rolfe, J., Evans, N.P., Herwartz, D., Staubwasser, M., Hodell, D.A. (2015). Simultaneous analysis of $170 / 160,180 / 160$ and $2 \mathrm{H} / 1 \mathrm{H}$ of gypsum hydration water by cavity ringdown laser spectroscopy. Rapid Communications in Mass Spectrometry, 29, pp. 1997-2006.

Giuliani, A., Phillips, D., Kamenetsky, V., Fiorentini, M., Farquhar, J. and Kendrick, M. (2014). Stable isotope $(\mathrm{C}, \mathrm{O}, \mathrm{S})$ compositions of volatile-rich minerals in kimberlites: A review. Chemical Geology, 374-375, pp.61-83.

Gonfiantini, R. and Fontes, J. (1963). Oxygen Isotopic Fractionation in the Water of Crystallization of Gypsum. Nature, 200(4907), pp.644-646.

Gutiérrez, F. (2004). Origin of the salt valleys in the Canyonlands section of the Colorado Plateau: Evaporite-dissolution collapse versus tectonic subsidence. Geomorphology, 57(3), 423-435.

Hardie, L. (1987). Dolomitization; a critical view of some current views. Journal of Sedimentary Research, 57(1), pp.166-183.

Haszeldine, R., Quinn, O., England, G., Wilkinson, M., Shipton, Z., Evans, J., Heath, J., Crossey, L., Ballentine, C. and Graham, C. (2005). Natural Geochemical Analogues for Carbon Dioxide Storage in Deep Geological Porous Reservoirs, a United Kingdom Perspective. Oil \& Gas Science and Technology - Rev. IFP, 60(1), pp.33-49.

Heath, J., Lachmar, T.E., Evans, J.P., Kolesar, P.T., and Williams, A.P. (2004). Hydrogeochemical characterization of leaking, carbon dioxide charged fault zones in east-central Utah with implications for geologic carbon storage. In:McPherson, B.J. and Sundquist, E. (Eds.), Carbon Sequestration and Its Role in the Global Carbon Cycle: American Geophysical Union Monograph Series 183, Washington, American Geophysical Union, pp. 147-158.

Hodell, D., Turchyn, A., Wiseman, C., Escobar, J., Curtis, J., Brenner, M., Gilli, A., Mueller, A., Anselmetti, F., Ariztegui, D. and Brown, E. (2012). Late Glacial temperature and precipitation changes in the lowland Neotropics by tandem measurement of $\delta^{18} \mathrm{O}$ in biogenic carbonate and gypsum hydration water. Geochimica et Cosmochimica Acta, 77, pp.352-368. 
Hoering, T. and Kennedy, J. (1957). The Exchange of Oxygen between Sulfuric Acid and Water 1. J. Am. Chem. Soc., 79(1), pp.56-60.

Kampman, N., Bickle, M., Becker, J., Assayag, N., and Chapman, H. (2009). Feldspar dissolution kinetics and Gibbs free energy dependence in a $\mathrm{CO}_{2}$-enriched groundwater system, Green River, Utah. Earth and Planetary Science Letters, 284 (3-4), pp 473-488.

Kampman, N., Burnside, N., Shipton, Z., Chapman, H., Nicholl, J., Ellam, R. and Bickle, M. (2012). Pulses of carbon dioxide emissions from intracrustal faults following climatic warming. Nature Geoscience, 5(5), pp.352-358.

Kampman, N., Maskell, A., Bickle, M.J., Evans, J.P., Schaller, M., Purser, G., Zhou, Z., Gattacceca, J., Peitre, E.S., Rochelle, C.A., Ballentine, C.J., Busch, A., scientists of the GRDP. (2013). Scientific drilling and downhole fluid sampling of a natural $\mathrm{CO}_{2}$ reservoir, Green River, Utah. Sci. Drill. 16, 33-43.

Kampman, N., Bickle, M., Maskell, A., Chapman, H., Evans, J., Purser, G., Zhou, Z., Schaller, M., Gattacceca, J., Bertier, P., Chen, F., Turchyn, A., Assayag, N., Rochelle, C., Ballentine, C. and Busch, A. (2014). Drilling and sampling a natural $\mathrm{CO}_{2}$ reservoir: Implications for fluid flow and $\mathrm{CO}_{2}$-fluid-rock reactions during $\mathrm{CO}_{2}$ migration through the overburden. Chemical Geology, 369, pp.51-82.

Kaszuba, J., Navarre-Sitchler, A., Thyne, G., Chopping, C. and Meuzelaar, T. (2011). Supercritical carbon dioxide and sulfur in the Madison Limestone: A natural analog in southwest Wyoming for geologic carbon-sulfur co-sequestration. Earth and Planetary Science Letters, 309, 131-140.

Kirk, M. (2011). Variation in Energy Available to Populations of Subsurface Anaerobes in Response to Geological Carbon Storage. Environmental Science \& Technology, 45(15), pp.6676-6682.

Knauss, K., Johnson, J. and Steefel, C. (2005). Evaluation of the impact of $\mathrm{CO}_{2}$, co-contaminant gas, aqueous fluid and reservoir rock interactions on the geologic sequestration of $\mathrm{CO}_{2}$. Chemical Geology, 217(3-4), pp.339-350.

Kummerow, J. and Spangenberg, E. (2011). Experimental evaluation of the impact of the interactions of $\mathrm{CO}_{2}-\mathrm{SO}_{2}$, brine, and reservoir rock on petrophysical properties: A case study from the Ketzin test site, Germany. Geochemistry, Geophysics, Geosystems, 12(5). 
Kusakabe, M. and Robinson, B. (1977). Oxygen and sulfur isotope equilibria in the BaSO4 $\mathrm{HSO} 4-\mathrm{H} 2 \mathrm{O}$ system from 110 to $350^{\circ} \mathrm{C}$ and applications. Geochimica et Cosmochimica Acta, 41(8), pp.1033-1040.

Lloyd, R. (1967). Oxygen-18 Composition of Oceanic Sulfate. Science, 156(3779), pp.12281231.

Lloyd, R. (1968). Oxygen isotope behavior in the Sulfate-Water System. Journal of Geophysical Research, 73(18), pp.6099-6110.

Matsubaya, O. and Sakai, H. (1973). Oxygen and hydrogen isotopic study on the water of crystallization of gypsum from the Kuroko type mineralization. Geochem. J., 7(3), pp.153-165.

Metzger, J., Fike, D., Osburn, G., Guo, C. and Aadison, A. (2015). The source of gypsum in Mammoth Cave, Kentucky. Geology, 43(2), pp.187-190.

Moore, J., Adams, M., Allis, R., Lutz, S. and Rauzi, S. (2005). Mineralogical and geochemical consequences of the long-term presence of $\mathrm{CO}_{2}$ in natural reservoirs: An example from the Springerville-St. Johns Field, Arizona, and New Mexico, U.S.A. Chemical Geology, 217(3-4), pp.365-385.

Morozova, D., Wandrey, M., Alawi, M., Zimmer, M., Vieth, A., Zettlitzer, M. and Würdemann, $H$. (2010). Monitoring of the microbial community composition in saline aquifers during $\mathrm{CO}_{2}$ storage by fluorescence in situ hybridisation. International Journal of Greenhouse Gas Control, 4(6), pp.981-989.

Nuccio, V.F. and Condon, S.M. (1996). Burial and thermal history of the Paradox basin, Utah and colorado, and the petroleum potential of the Middle Pennsylvanian Paradox formation. U.S. Geological Survey Bulletin, 2000-O, pp. 01-041.

Ostroff, A. G. (1964). Conversion of gypsum to anhydrite in aqueous salt solutions. Geochimica et Cosmochimica Acta 28(9), pp. 1363-1372.

Peterson, F. and Turner-Peterson, C. (1989). IGC Field Trip T130: Geology of the Colorado Plateau, in Geology of the Colorado Plateau: Grand Junction to Denver, Colorado June 30-July 7, 1989 (eds F. Peterson and C. Turner-Peterson), American Geophysical Union, Washington, D. C. 
Petrychenko, O., Williams-Stroud, S. and Peryt, T. (2012). The relationship of brine chemistry of the Pennsylvanian Paradox Evaporite Basin (southwestern USA) to secular variation in seawater chemistry.Geological Quarterly, 56(1), pp.25-40.

Rennie, V. C. F. and Turchyn, A. V. (2014). Controls on the abiotic exchange between aqueous sulfate and water under laboratory conditions. Limnology and Oceanography: methods, 12, pp. 166-173.

Rudnicki M. D., Elderfield H., and Spiro B. (2001) Fractionation of sulfur isotopes during bacterial sulfate reduction in deep ocean sediments at elevated temperatures. Geochimica et Cosmochimica Acta 65, pp. 777-789.

Samborska, K., Halas, S. and Bottrell, S. (2013). Sources and impact of sulphate on groundwaters of Triassic carbonate aquifers, Upper Silesia, Poland. Journal of Hydrology, 486, pp.136-150.

Saraji, S., Piri, M. and Goual, L. (2014). The effects of $\mathrm{SO}_{2}$ contamination, brine salinity, pressure, and temperature on dynamic contact angles and interfacial tension of supercritical $\mathrm{CO}_{2} /$ brine/quartz systems. International Journal of Greenhouse Gas Control, 28, pp.147-155.

Schaef, H., Horner, J., Owen, A., Thompson, C., Loring, J., and McGrail, B. (2014). Mineralization of Basalts in the $\mathrm{CO}_{2}-\mathrm{H}_{2} \mathrm{O}-\mathrm{SO}_{2}-\mathrm{O}_{2}$ System. Environmental Science and Technology, 48, pp. 5298-5305.

Shearman, D.J. (1985). Syndepositional and late diagenetic alteration of gypsum to anhydrite. 6th International Symposium on Salt, The Salt Institute, 1, pp. 41-55.

Shipton, Z., Evans, J., Kirschner, D., Kolesar, P., Williams, A. and Heath, J. (2004). Analysis of $\mathrm{CO} 2$ leakage through 'low-permeability' faults from natural reservoirs in the Colorado Plateau, east-central Utah. Geological Society, London, Special Publications, 233(1), pp.43-58.

Soetaert, K., Hofmann, A.F., Middelburg, J.J., Meysman, F.J.R. and Greenwood, J. (2007). The effect of biogeochemical processes on pH. Marine Chemistry, 105(1-2), 3051.

Sofer, Z. (1978). Isotopic composition of hydration water in gypsum. Geochimica et Cosmochimica Acta, 42(8), pp.1141-1149. 
Surkov, A., Böttcher, M. and Kuever, J. (2012). Sulphur isotope fractionation during the reduction of elemental sulphur and thiosulphate by Dethiosulfovibrio spp. Isotopes in Environmental and Health Studies, 48(1), pp.65-75.

Taylor, J. and Hood, W J. (1988). Region 3, Colorado Plateau and Wyoming Basin in Back, W., Rosenshein, J., and Seaber, P., eds. Hydrogeology: Boulder, Colorado. Geological Society of North America. The Geology of North America, V-O2, pp. 51-58.

Van Stempvoort, D., Reardon, E. and Fritz, P. (1990). Fractionation of sulfur and oxygen isotopes in sulfate by soil sorption. Geochimica et Cosmochimica Acta, 54(10), pp.2817-2826.

Verlander, J. (1995). The Navajo Sandstone. Geology Today, 11(4), pp.143-146.

Wigley, M., Kampman, N., Dubacq, B., Bickle, M. (2012). Fluid-mineral reactions and trace metal mobilization in an exhumed natural $\mathrm{CO}_{2}$ reservoir, Green River, Utah. Geology, 40 (6), pp. 555-558.

Wilkinson, M., Gilfillan, S.V.M., Haszeldine, R.S., and Ballentine, C.J. (2009.) Plumbing the depths: testing natural tracers of subsurface $\mathrm{CO}_{2}$ origin and migration, Utah. In Grobe, M., Pashin, J.C., Dodge, R.L., eds., Carbon Dioxide Sequestration in Geological MediaState of the Science, AAPG Studies in Geology, pp. 619-634. Tulsa, OK: American Association of Petroleum Geologists.

975

Williams-Stroud, S. (1994). Solution to the Paradox? Results of some chemical equilibrium and mass balance calculations applied to the Paradox Basin evaporite deposit. American Journal of Science, 294(10), pp.1189-1228.

Xu, T., Apps, J., Pruess, K. and Yamamoto, H. (2007). Numerical modeling of injection and mineral trapping of $\mathrm{CO}_{2}$ with $\mathrm{H}_{2} \mathrm{~S}$ and $\mathrm{SO}_{2}$ in a sandstone formation. Chemical Geology, 242(3-4), pp.319-346.

Zeebe, R. (2010). A new value for the stable oxygen isotope fractionation between dissolved sulfate ion and water. Geochimica et Cosmochimica Acta, 74(3), pp.818-828. 
Table 1 - Isotopic composition of the secondary gypsum veins in the Jurassic Entrada Sandstone. Samples with the same name and multiple numbers (e.g. E1, E2, E3...) were single veins that were microdrilled to look for intravein heterogeneity. All oxygen measurements were duplicated, with the exception of those sample names with a 3 or 6 as a subscript. These were measured three or six times. All measurements were conducted in July 2013 with the exception of those with a letter $O$ in the subscript, which were conducted in October 2014.

\begin{tabular}{|c|c|c|c|c|c|}
\hline Sample Name & Depth (m) & $\delta 34 \mathrm{~S}$ & stdev & $\delta 180$ & stdev \\
\hline V22 U1 & 19.12 & 11.9 & 0.16 & 12.0 & 0.17 \\
\hline V22 L1 & 19.12 & 11.8 & 0.41 & 12.8 & 0.56 \\
\hline V22 L2 & 19.12 & 11.6 & 0.41 & 12.5 & 0.13 \\
\hline V22 L3 & 19.12 & 11.7 & 0.41 & 12.7 & 0.25 \\
\hline $\mathrm{GVO}_{3} 9_{3}$ & 47.06 & 11.8 & 0.21 & 12.0 & 0.06 \\
\hline $222.24_{0,3}$ & 67.74 & 11.6 & 0.24 & 11.9 & 1.24 \\
\hline $222.84_{0,3}$ & 67.92 & 10.6 & 0.24 & 10.8 & 0.86 \\
\hline GV001 223 E1 & 67.97 & 11.8 & 0.06 & 12.3 & 0.01 \\
\hline GV001 223 E2 & 67.97 & 11.6 & 0.28 & 9.7 & 0.45 \\
\hline GV001 223 E3 & 67.97 & 11.7 & 0.28 & 12.4 & 0.15 \\
\hline GV001 223 E4 & 67.97 & 11.6 & 0.28 & 12.6 & 0.25 \\
\hline GV001 223 E5 & 67.97 & 11.4 & 0.28 & 12.1 & 0.08 \\
\hline GV001 223 E M1 & 67.97 & 11.8 & 0.06 & 14.0 & 0.25 \\
\hline GV001 223 E M2 & 67.97 & 11.6 & 0.28 & 14.2 & 0.14 \\
\hline GV001 223 E M3 & 67.97 & 11.7 & 0.28 & 14.2 & 0.20 \\
\hline GV001 223 E M4 & 67.97 & 11.6 & 0.28 & 14.0 & 0.10 \\
\hline GV001 223 E M5 & 67.97 & 11.4 & 0.28 & 13.3 & 0.22 \\
\hline GV001 223 E M6 & 67.97 & 11.8 & 0.06 & 13.9 & 0.02 \\
\hline GV001 223 E M7 & 67.97 & 11.6 & 0.28 & 12.8 & 0.13 \\
\hline GV001 223 E M8 & 67.97 & 11.7 & 0.28 & 14.4 & 0.28 \\
\hline GV001 223 E M9 & 67.97 & 11.6 & 0.28 & 14.0 & 0.23 \\
\hline GV001 223 E M10 & 67.97 & 11.4 & 0.28 & 14.2 & 0.24 \\
\hline GV048 o,6 & 69.31 & 11.5 & 0.22 & 11.2 & 0.37 \\
\hline $250.2 \mathrm{E} 1$ & 76.26 & 11.9 & 0.63 & 12.4 & 0.29 \\
\hline $250.2 \mathrm{E} 2$ & 76.26 & 11.9 & 0.39 & 12.4 & 0.49 \\
\hline $250.2 \mathrm{E} 3$ & 76.26 & 12.5 & 0.39 & 6.6 & 0.30 \\
\hline $250.2 \mathrm{E} 4$ & 76.26 & 12.5 & 0.22 & 3.6 & 0.77 \\
\hline $250.2 \mathrm{E} \mathrm{M} 1$ & 76.26 & 11.9 & 0.63 & 12.9 & 0.13 \\
\hline 250.2 E M2 & 76.26 & 11.9 & 0.39 & 13.0 & 0.27 \\
\hline $250.2 \mathrm{E} \mathrm{M} 3$ & 76.26 & 12.5 & 0.39 & 13.0 & 0.02 \\
\hline 250.2 E M4 & 76.26 & 12.5 & 0.22 & 12.5 & 0.00 \\
\hline 250.2 E M5 & 76.26 & 11.9 & 0.63 & 13.2 & 0.02 \\
\hline 250.2 E M6 & 76.26 & 11.9 & 0.39 & 11.5 & 0.05 \\
\hline 250.2 E M7 & 76.26 & 12.5 & 0.39 & 11.5 & 0.33 \\
\hline $250.2 \mathrm{E} \mathrm{M} 8$ & 76.26 & 12.5 & 0.22 & 12.2 & 0.15 \\
\hline $\mathrm{ESS} 123_{0,3}$ & 76.26 & 10.8 & 0.24 & 10.0 & 0.19 \\
\hline 303.52 & 92.51 & 11.5 & 0.41 & 10.2 & 0.32 \\
\hline
\end{tabular}


Table 2 - Isotopic composition of the gypsum beds and secondary gypsum veins in the Jurassic Carmel Formation. Samples with the same name and multiple numbers (e.g. C1, C2, C3...) were single veins that were microdrilled to look for intravein heterogeneity. All oxygen measurements were run in triplicate, with the exception of those sample names with a 2 or 6 as a subscript. These were measured two or six times. All measurements were conducted in July 2013 with the exception of those with an N or JA subscript, which were conducted in November 2014, or January 2015.

\begin{tabular}{|c|c|c|c|c|c|c|}
\hline Sample Name & Depth (m) & Formation & $\delta 34 \mathrm{~S}$ & stdev & $\delta 180$ & stdev \\
\hline GV010 & 158.48 & Carmel Bed & 15.9 & 0.21 & 10.9 & 0.14 \\
\hline GV01B JA $_{\text {J }}$ & 158.48 & Carmel Bed & 15.1 & 0.24 & 7.8 & 0.81 \\
\hline GV13B & 158.79 & Carmel Bed & 15.3 & 0.21 & 10.5 & 0.11 \\
\hline $522.0 \mathrm{Cl}_{2}$ & 159.11 & Carmel Bed & 15.6 & 0.52 & 9.4 & 0.18 \\
\hline $522.0 \mathrm{C}_{2} 2$ & 159.11 & Carmel Bed & 15.2 & 0.28 & 11.5 & 0.57 \\
\hline $522.0 \mathrm{C} 32$ & 159.11 & Carmel Bed & 15.4 & 0.89 & 11.1 & 0.33 \\
\hline $522.0 \mathrm{C}_{4}$ & 159.11 & Carmel Bed & 15.3 & 0.28 & 12.0 & 0.22 \\
\hline $522.0 \mathrm{C} 52$ & 159.11 & Carmel Bed & 15.3 & 0.28 & 11.3 & 0.51 \\
\hline GV015 & 159.17 & Carmel Bed & 15.6 & 0.21 & 10.9 & 0.12 \\
\hline GV018B $_{\text {JA }}$ & 159.64 & Carmel Bed & 14.9 & 0.24 & 8.4 & 1.18 \\
\hline GB005 ${ }_{N}$ & 160.29 & Carmel Bed & 14.7 & 0.24 & 9.6 & 0.22 \\
\hline GV019 & 160.36 & Carmel Bed & 16.1 & 0.21 & 11.7 & 0.30 \\
\hline $\mathrm{GV019B}_{\mathrm{JA}}$ & 160.36 & Carmel Bed & 15.2 & 0.24 & 8.3 & 0.69 \\
\hline $\mathrm{GV047B}_{\mathrm{JA}}$ & 160.91 & Carmel Bed & 15.6 & 0.24 & 9.2 & 1.29 \\
\hline GV021B & 161.80 & Carmel Bed & 15.1 & 0.24 & 9.7 & 0.73 \\
\hline GV021 & 161.80 & Carmel Bed & 15.2 & 0.21 & 11.5 & 0.19 \\
\hline $\mathrm{GV}_{025 \mathrm{~B}_{\mathrm{JA}}}$ & 163.07 & Carmel Bed & 15.3 & 0.24 & 8.1 & 1.10 \\
\hline GV031 ${ }_{\mathrm{N}}$ & 167.25 & Carmel Bed & 15.1 & 0.24 & 10.2 & 0.39 \\
\hline GV032 & 167.76 & Carmel Bed & 15.8 & 0.21 & 10.9 & 0.36 \\
\hline GV002 & 154.99 & Carmel Vein & 12.8 & 0.21 & 12.2 & 0.11 \\
\hline GV003 & 156.00 & Carmel Vein & 13.0 & 0.21 & 11.4 & 0.10 \\
\hline GV004 & 156.24 & Carmel Vein & 13.0 & 0.21 & 10.9 & 0.08 \\
\hline GV006 & 156.79 & Carmel Vein & 14.0 & 0.21 & 11.1 & 0.28 \\
\hline $519.5 \mathrm{C} 1(\mathrm{~GB} 001)_{2}$ & 158.34 & Carmel Vein & 15.7 & 0.08 & 12.5 & 0.34 \\
\hline $519.5 \mathrm{C} 2(\mathrm{~GB} 001)_{2}$ & 158.34 & Carmel Vein & 15.5 & 0.10 & 10.9 & 0.12 \\
\hline $519.5 \mathrm{C} 3(\mathrm{~GB} 001)_{2}$ & 158.34 & Carmel Vein & 15.6 & 0.37 & 11.2 & 0.05 \\
\hline $519.5 \mathrm{C} 4(\mathrm{~GB} 001)_{2}$ & 158.34 & Carmel Vein & 15.1 & 0.10 & 12.6 & 0.20 \\
\hline $\mathrm{GB} 001_{\mathrm{JA}}$ & 158.34 & Carmel Vein & 14.9 & 0.24 & 9.1 & 1.23 \\
\hline GV13L & 158.79 & Carmel Vein & 14.9 & 0.21 & 10.4 & 0.20 \\
\hline GV002 JA & 159.11 & Carmel Vein & 14.7 & 0.24 & 7.6 & 0.47 \\
\hline GV023 & 162.19 & Carmel Vein & 15.7 & 0.21 & 10.8 & 0.17 \\
\hline GV024 & 162.31 & Carmel Vein & 15.0 & 0.21 & 10.6 & 0.15 \\
\hline GV021-1 JA & 162.31 & Carmel Vein & 15.0 & 0.24 & 8.2 & 0.98 \\
\hline GV025 & 163.07 & Carmel Vein & 15.9 & 0.21 & 11.3 & 0.09 \\
\hline $\mathrm{GV} 027_{\mathrm{N}}$ & 164.10 & Carmel Vein & 14.6 & 0.24 & 10.3 & 0.49 \\
\hline GV028 JA & 165.55 & Carmel Vein & 15.0 & 0.24 & 8.3 & 0.89 \\
\hline GV030 & 166.98 & Carmel Vein & 16.1 & 0.21 & 12.8 & 0.08 \\
\hline $\mathrm{GV} 003_{\mathrm{N}}$ & 168.14 & Carmel Vein & 14.5 & 0.24 & 10.8 & 0.69 \\
\hline $551.65 \mathrm{Cl}_{2}$ & 168.14 & Carmel Vein & 16.0 & 0.28 & 10.9 & 0.07 \\
\hline $551.65 \mathrm{C} 2_{2}$ & 168.14 & Carmel Vein & 15.1 & 0.28 & 10.5 & 0.32 \\
\hline $551.65 \mathrm{C} 3{ }_{2}$ & 168.14 & Carmel Vein & 16.1 & 0.05 & 7.9 & 0.06 \\
\hline $551.65 \mathrm{C}_{4}$ & 168.14 & Carmel Vein & 16.0 & 0.28 & 10.6 & 0.35 \\
\hline GV033 JA & 168.26 & Carmel Vein & 15.0 & 0.24 & 9.2 & 0.93 \\
\hline $\mathrm{GV034}_{\mathrm{JA}, 6}$ & 168.37 & Carmel Vein & 14.7 & 0.22 & 9.4 & 0.24 \\
\hline GV036 & 169.13 & Carmel Vein & 14.9 & 0.21 & 11.5 & 0.07 \\
\hline GV037 JA & 169.77 & Carmel Vein & 15.5 & 0.24 & 10.5 & 1.31 \\
\hline GV042 & 172.38 & Carmel Vein & 15.0 & 0.21 & 10.3 & 0.11 \\
\hline $\mathrm{GV044}_{\mathrm{JA}}$ & 172.96 & Carmel Vein & 14.5 & 0.24 & 9.0 & 0.62 \\
\hline GV046 & 174.70 & Carmel Vein & 15.3 & 0.21 & 11.3 & 0.17 \\
\hline $639.5 \mathrm{Cl}_{2}$ & 194.92 & Carmel Vein & 11.1 & 0.17 & 11.5 & 1.27 \\
\hline $639.5 \mathrm{C} 2{ }_{2}$ & 194.92 & Carmel Vein & 10.1 & 0.27 & 10.4 & 0.20 \\
\hline $641.5 \mathrm{C}_{2}$ & 195.53 & Carmel Vein & 10.9 & 0.41 & 12.3 & 0.16 \\
\hline $641.5 \mathrm{C} 2{ }_{2}$ & 195.53 & Carmel Vein & 11.1 & 0.41 & 11.1 & 0.26 \\
\hline $641.5 \mathrm{C} 3_{2}$ & 195.53 & Carmel Vein & 10.6 & 0.41 & 11.8 & 0.55 \\
\hline
\end{tabular}


Table 3 - Isotopic composition of the evaporites in the Paradox Formation. All measurements were collected in November 2014, and all oxygen samples were run in triplicate.

\begin{tabular}{|c|c|c|c|c|c|}
\hline Name & Depth $(\mathbf{m})$ & $\mathbf{\delta 3 4} \mathbf{~ S}$ & stdev & $\boldsymbol{\delta 1 8 ~ O}$ & stdev \\
\hline Care Creek 1 & 243.05 & 13 & 0.18 & 10.5 & 0.8 \\
\hline Care Creek 1 & 248.32 & 13.1 & 0.18 & 9.7 & 0.46 \\
\hline Shafer 1 & 303.43 & 12.9 & 0.18 & 10.3 & 0.68 \\
\hline Shafer 1 & 315.22 & 12.9 & 0.18 & 10.7 & 0.41 \\
\hline Shafer 1 & 323.3 & 12.4 & 0.18 & 10.9 & 0.98 \\
\hline Shafer 1 & 345.92 & 12.1 & 0.18 & 11.6 & 0.8 \\
\hline Shafer 1 & 358.23 & 11.3 & 0.18 & 10.9 & 0.57 \\
\hline Gibson Dome & 417.94 & 12.3 & 0.18 & 12.2 & 0.56 \\
\hline
\end{tabular}


Table 4 - Isotopic composition of the gypsum hydration water, including the calculated isotopic composition of the mother water. For samples from which no hydration water was extracted, we show the \% water. These samples had already dehydrated to anhydrite.

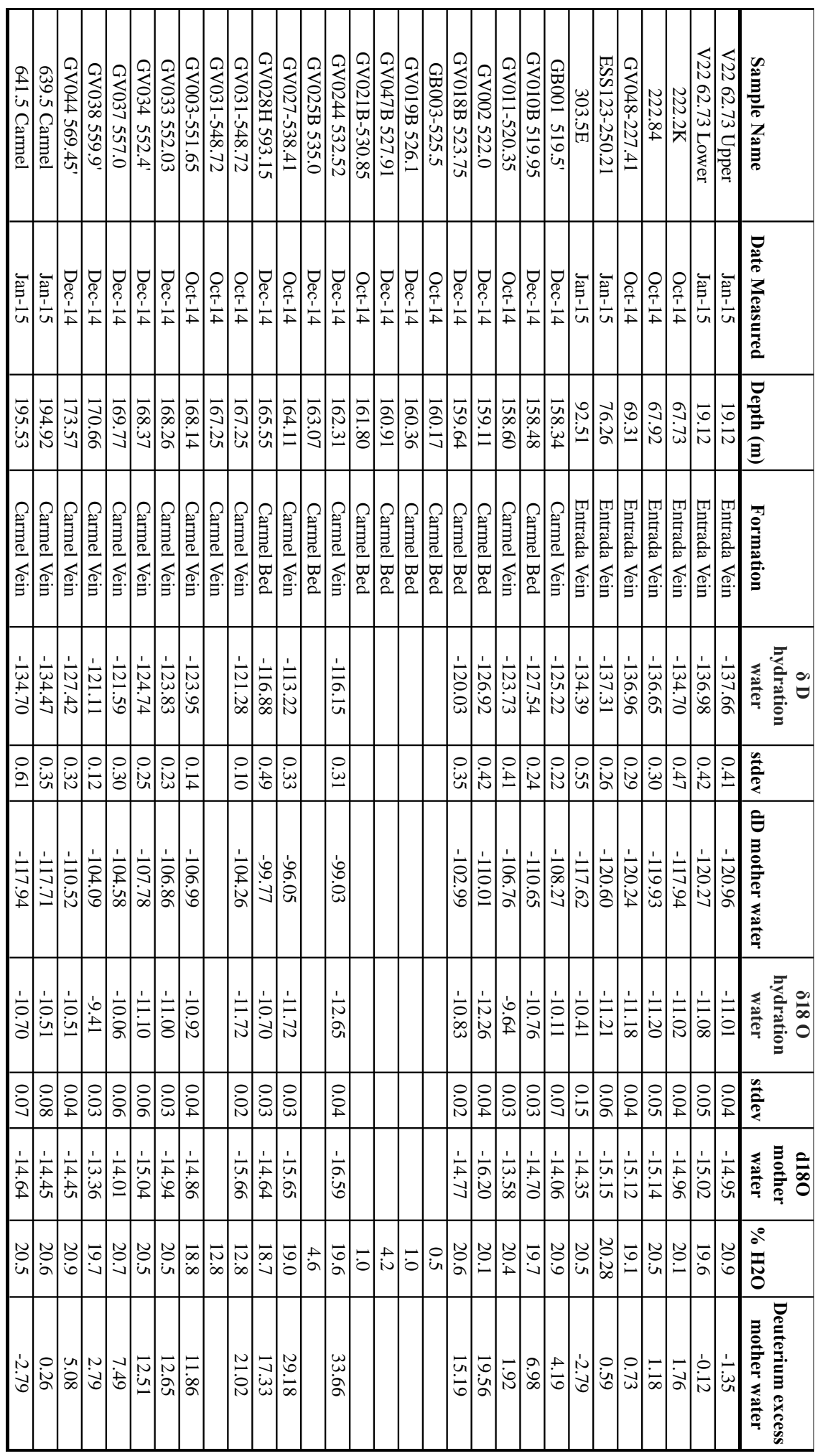


1060 Table 5 - Sulfur isotopic composition of disseminated pyrite in the Entrada Sandstone. All samples were measured in July 2013.

\begin{tabular}{|c|c|c|c|c|}
\hline Name & Depth(m) & Formation & $\mathbf{8 3 4} \mathbf{S}$ & stdev \\
\hline V22 62.73 & 19.12 & Entrada & 17.24 & 0.36 \\
\hline $73.9 \mathrm{E}$ & 22.52 & Entrada & -47.39 & 0.21 \\
\hline PG 103E & 31.39 & Entrada & -9.62 & 0.21 \\
\hline $147 \mathrm{E}$ & 44.81 & Entrada & -16.16 & 0.21 \\
\hline $162.8 \mathrm{E}$ & 49.62 & Entrada & -32.46 & 0.21 \\
\hline $250.7 \mathrm{E}$ & 76.41 & Entrada & -6.13 & 0.21 \\
\hline $299 \mathrm{~L}$ & 91.14 & Entrada & 0.52 & 0.36 \\
\hline $299 \mathrm{D}$ & 91.14 & Entrada & -16.08 & 2.25 \\
\hline $322 \mathrm{E}$ & 98.15 & Entrada & 13.11 & 0.21 \\
\hline $392.2 \mathrm{E}$ & 119.54 & Entrada & -3.3 & 0.21 \\
\hline $416 \mathrm{E}$ & 126.8 & Entrada & 18.82 & 0.21 \\
\hline $449.9 \mathrm{E}$ & 137.13 & Entrada & 2.54 & 0.21 \\
\hline $491.6 \mathrm{D}$ & 149.84 & Entrada & 0.1 & 0.36 \\
\hline
\end{tabular}

